Annu Rev Immunol. 2012 ; 30: 115-148. doi:10.1146/annurev-immunol-020711-074958.

\title{
Adaptive Immunity to Fungi
}

\author{
Marcel Wüthrich ${ }^{1}$, George S. Deepe Jr. ${ }^{4,5}$, and Bruce Klein ${ }^{1,2,3}$ \\ ${ }^{1}$ Department of Pediatrics, University of Wisconsin School of Medicine and Public Health, \\ Madison, Wisconsin 53792 \\ ${ }^{2}$ Department of Internal Medicine, University of Wisconsin School of Medicine and Public Health, \\ Madison, Wisconsin 53792 \\ ${ }^{3}$ Department of Medical Microbiology and Immunology, University of Wisconsin School of \\ Medicine and Public Health, Madison, Wisconsin 53792 \\ ${ }^{4}$ Veterans Affairs Hospital, Cincinnati, Ohio 45220 \\ ${ }^{5}$ Division of Infectious Diseases, University of Cincinnati College of Medicine, Cincinnati, Ohio \\ 45267
}

\begin{abstract}
Only a handful of the more than 100,000 fungal species on our planet cause disease in humans, yet the number of life-threatening fungal infections in patients has recently skyrocketed as a result of advances in medical care that often suppress immunity intensely. This emerging crisis has created pressing needs to clarify immune defense mechanisms against fungi, with the ultimate goal of therapeutic applications. Herein, we describe recent insights in understanding the mammalian immune defenses deployed against pathogenic fungi. The review focuses on adaptive immune responses to the major medically important fungi and emphasizes how dendritic cells and subsets in various anatomic compartments respond to fungi, recognize their molecular patterns, and signal responses that nurture and shape the differentiation of T cell subsets and B cells. Also emphasized is how the latter deploy effector and regulatory mechanisms that eliminate these nasty invaders while also constraining collateral damage to vital tissue.
\end{abstract}

\section{Keywords}

dendritic cells; pattern-recognition receptors; T lymphocytes; chemokines; chemokine receptors

\section{INTRODUCTION}

Fungi are among the most common microbes encountered by mammalian hosts. They comprise $45 \%$ of coarse matter in the rainforest and $4-11 \%$ in rural and urban air. Approximately 1-10 fungal spores are inhaled with each breath taken (1). The natural route of infection for most fungal pathogens, not surprisingly, is via spores inhaled through the respiratory tract. Despite the abundance of fungal species in the environment, few are human pathogens (2). Medically important fungi include Histoplasma capsulatum, Paracoccidioides brasiliensis, Coccidioides immitis and posadasii, Blastomyces dermatitidis, Cryptococcus

Copyright $@ 2012$ by Annual Reviews. All rights reserved mwuethri@wisc.edu, bsklein@wisc.edu, george.deepe@uc.edu.

DISCLOSURE STATEMENT

The authors are not aware of any affiliations, memberships, funding, or financial holdings that might be perceived as affecting the objectivity of this review. 
neoformans, Aspergillus fumigatus, Pneumocystis jirovecii, and Candida albicans. Some of these, like $C$. albicans, also are commensal organisms in humans until the host becomes immune deficient, which can lead to life-threatening disease (3).

With the increase in AIDS cases worldwide and recent medical advances in transplantation and cancer treatment, the number of immune-compromised hosts has risen, also increasing the incidence of fungal diseases (4). Opportunistic fungi, such as Candida and Aspergillus sp., have become major concerns in caring for immune-compromised patients. Candida sp. are the fourth most important cause of hospital-acquired bloodstream infections. Up to $90 \%$ of HIV patients suffer from mucosal candidiasis at least once (5). Aspergillus and other mold infections are leading causes of death in hematopoietic stem cell transplant recipients (3).

Fungi also cause systemic infections in immune-competent hosts. Histoplasmosis, blastomycosis, and coccidiodomycoses are major endemic mycoses in the United States, infecting both immune-competent and immune-compromised patients. Eighty-seven percent of the patients who died from these infections were immune competent, and the number of infections is increasing every year (6).

Although not the subject of this review, fungi also can induce allergic diseases. There is a correlation between severe asthma and type I hypersensitivity to fungi. Patients with asthma and cystic fibrosis have increased rates of sensitization to molds and show autoreactivity to environmental fungi and self-antigens (7-9).

There is a pressing need to develop fungal vaccines because antifungal therapy may be toxic and ineffective (10). Presently, there is no vaccine for any human mycosis. A clear understanding of the mechanisms of adaptive immunity would foster the development of vaccines and advance the development of biological therapeutics that are used to modulate the host's immune response. The ubiquity of fungi in our environment and the commensal relationship of some fungi with humans may make eliciting immunity a challenge, owing to repeated exposure or sensitivity to fungal antigens (11). Furthermore, upsetting the immune balance with commensal organisms may lead to detrimental allergic or autoimmune diseases. The generation of antifungal immunity presents a challenge, posing a fine line between fostering pathogen clearance, restraining tissue damage, and preserving the balance of the natural microbiota.

Here, we review recent advances in the knowledge of adaptive immunity to fungi. Although these insights lay a foundation needed for vaccines, the topic of vaccines per se is not covered here because it was the subject of another review (4). The present review focuses on aspects of antifungal immunity that include dendritic cell (DC) subsets, fungal patternrecognition receptors (PRRs) and their downstream signaling pathways, and the ensuing products that nurture and sculpt effectors that rid tissues of fungi while constraining damage.

\section{DENDRITIC CELLS: LINKING INNATE AND ADAPTIVE IMMUNE RESPONSES}

\section{Bridging Innate and Adaptive Immunity}

The induction of innate immunity through the activation of PRRs provides the foundation to develop an adaptive immune response $(13,14)$. DCs bridge innate and adaptive immunity by shaping the $\mathrm{T}$ cell response following PRR-dependent cytokine production. Only DCs are able to prime naive $\mathrm{T}$ cells to generate life-long memory against pathogens. $\mathrm{T}$ cell priming by DCs occurs through the presentation of pathogen-associated antigen on MHC class I or MHC class II molecules for the priming of $\mathrm{CD}^{+}$or $\mathrm{CD} 4^{+} \mathrm{T}$ cells, respectively, in addition 
to the expression of costimulatory molecules for proper T cell receptor (TCR) stimulation. DCs increase costimulatory molecule expression upon maturation, and they possess abundant PRRs on the cell surface for direct interaction with pathogens, thereby translating signals from PRRs to T cells $(14,15)$. After the activation of $T$ cells, the response is often described as Th1, Th2, Th17, or T regulatory (Treg) with respect to different schemes of cytokine production by $\mathrm{T}$ helper CD4 T cells. Thus, the ability to control the fate of the immune response makes DCs both central to balancing immunity and a prime target for vaccine development against the fungi.

\section{Characterizing Dendritic Cell Subsets}

DCs are characterized into subsets based on their surface markers and function. Two main categories have been established: conventional (c)DCs and plasmacytoid (p)DCs, which are IFN- $a$ (type I interferon)-producing cells associated primarily with viral clearance and the induction of a regulatory response (16). An important exception is the recent study linking pDCs to resistance to $A$. fumigatus infection, where they exert a nonredundant role in clearance of Aspergillus from the lung (17). In that study, human pDCs spread over hyphae and inhibited their growth (Figure 1). Hyphae induced pDC cytotoxicity, partly as a result of fungal gliotoxin secretion. Following hyphal stimulation, pDCs released proinflammatory cytokines via a Toll-like receptor (TLR)9-independent mechanism. Pulmonary challenge of mice with $A$. fumigatus resulted in a substantial influx of pDCs into lungs, and pDCdepleted mice were hypersusceptible to invasive aspergillosis.

Typically, most DC subsets are viewed as cDCs and are characterized by high CD11c expression and MHC class II on the surface (18). Comprehensive characterization of DC subsets can be achieved by various surface markers. The most notable are CD11c, CD11b, DEC205, DC-SIGN, Langerin, CD103, CD8, Ly6C, MHC class II, and PD-1 (19-22). The combination of markers defines the functional roles of DC subsets. For example, the major difference between cDCs and pDCs is B220, a B cell marker. In fact, pDCs are the only ones that express B220 (23). Most characterization of cDC subsets requires multiple surface markers, functional analysis, and knowledge of their peripheral location. Recent work on pDCs notwithstanding, in the context of host-fungal pathogen interactions, most studies have uncovered a role for cDCs. Hence, we focus here on cDC subsets in the draining lymph nodes and peripheral sites such as the skin and lung (Figure 1). The draining lymph nodes contain two major types of DCs: migratory DCs and lymph node-resident DCs.

\section{Lymph Node-Resident Dendritic Cells}

The lymphoid organs include the draining lymph nodes and the spleen as primary organs for priming $\mathrm{T}$ cells during infection. The blood-derived lymph node-resident DCs reside in the lymph nodes and spleen and are divided into three types: $\mathrm{CD} 4^{+}, \mathrm{CD} 8^{+}$, and double negative. These resident DCs are compartmentalized and show distinct functions within the secondary lymphoid organ. The CD8 marker generally indicates which $\mathrm{T}$ cell subset $\left(\mathrm{CD} 4^{+}\right.$or $\left.\mathrm{CD} 8^{+}\right)$ associates with the DC. In the spleen, the $\mathrm{CD} 8^{+} \mathrm{CD} 11 \mathrm{~b}^{-} \mathrm{DCs}$, located in the $\mathrm{T}$ cell zone, prime and cross-present exogenous antigen to $\mathrm{CD} 8^{+} \mathrm{T}$ cells (24). In contrast, $\mathrm{CD} 8^{-} \mathrm{CD} 11 \mathrm{~b}^{+}$ DCs, located in the red pulp and marginal zone, present antigen to $\mathrm{CD}^{+} \mathrm{T}$ cells $(25,26)$. DC cross-priming and -presentation induces $\mathrm{CD} 8^{+} \mathrm{T}$ cell responses to $H$. capsulatum (27), and these responses have a significant role in controlling infection in experimental pulmonary histoplasmosis (28). Because these DC studies were done in vitro with bone marrow DCs, the relevant subset and phenotype responsible for priming these CD8 T cell responses in vivo in the lung or spleen have not been identified.

In the skin-draining lymph node, lymph node-resident DCs are located near the high endothelial venules, whereas migratory DCs remain near the outer cortex $(29,30)$. 
Migratory DCs from the skin make their way to the T cell zone of the lymph node cortex to prime naive T cells (31). Lymph node-resident DCs also present antigen to T cells during the initial stages of inflammation or infection. These migratory and resident DC subsets interact and collaborate in priming $\mathrm{CD} 4^{+} \mathrm{T}$ cells to fungi, as described below for responses to $B$. dermatitidis in a vaccine model (32). Acquisition of antigen can occur passively through the draining lymphatics and/or through transfer from migratory DCs (29, 32-34). YA-e antibody detection of E $a$-peptide displayed by MHC class II revealed that lymph node-resident DCs acquire antigen in the skin-draining lymph node by 15-30 min following subcutaneous inoculation with soluble E $\boldsymbol{a}$-protein (35), indicating passive diffusion through the lymphatics as a method for antigen acquisition (34). This phenomenon was also seen in Leishmania infection, where lymph node-resident DCs activated T cells within hours of subcutaneous infection with Leishmania major (36). Thus, soluble antigen from a microbe arrives in the lymph node faster than migratory DCs can carry antigen from the site of infection; these migratory DCs appear in the lymph node after $1-2$ days $(33,37)$. Only the latter type of antigen delivery into the lymph node was observed during subcutaneous administration of live attenuated yeast in a model of vaccine-induced immunity to $B$. dermatitidis (32). In that study, although a soluble control protein antigen entered the draining node rapidly, vaccine yeast were ferried into the node by migratory DCs, appearing only after $24 \mathrm{~h}$ postvaccination.

\section{Migratory/Interstitial Dendritic Cells}

Interstitial DCs at various sites follow the classic Langerhans cell paradigm: They survey peripheral sites and transport and present antigen from invading pathogens to the lymphoid organs. Two types of migratory DCs are dermal or interstitial DCs and epidermal Langerhans cells (20). Several markers, particularly DEC205, CD8 a, Langerin, and, more recently, CD103, have been utilized to identify different subsets of interstitial DCs. Initially, the identifying characteristic for epidermal Langerhans cells was the presence of intracellular Langerin, although Langerin can also be found in some dermal DCs as well as in interstitial DCs in the lung, intestines, and spleen (38-41).

Skin-derived DCs are restricted to the dermis and epidermis, whereas intestinal DCs are present in the organized lymphoid tissues of the Peyer's patches and throughout the lamina propria. Dermal DCs in the dermal layer and Langerhans cells in the epidermis are primarily $\mathrm{CD} 8 \mathrm{a}^{+}$and $\mathrm{CD} 11 \mathrm{~b}^{+}$, and they express DEC205 isomeric forms, possible branch-points (42, 43). CD103 has recently been used to characterize dermal DC subsets $(26,44)$. Dermal DCs can be further divided into Langerin ${ }^{+}$or Langerin ${ }^{-}$subsets. DEC $205^{+}$dermal DCs contribute to priming $\mathrm{CD} 4^{+} \mathrm{T}$ cells upon subcutaneous vaccination against $B$. dermatitidis, although the independent roles of Langerin ${ }^{+}$and Langerin ${ }^{-}$subsets were not investigated (32).

Upon cutaneous epidermal exposure to $C$. albicans, three subsets of skin DCs- Langerhans, Langerin $^{+}$dermal DCs, and classic dermal DCs-were studied for their role in antigen presentation to see if they have distinct or redundant functions (Figure 1). Langerhans cells were found to be necessary and sufficient for the generation of antigen-specific Th17 cells, but not for the generation of cytotoxic $\mathrm{T}$ lymphocytes via cross-presentation (45). In this model, the Langerhans cells produced elevated levels of IL-6, IL-1 $\beta$, and IL-23, which promote and stabilize Th17 development. These DCs expressed low levels of IL-27 and no IL-12, which are key cytokines for Th1 differentiation. In contrast, Langerin ${ }^{+}$dermal DCs were required for cytotoxic T lymphocytes and Th1 cells. Compared with Langerhans cells, these cells also produced higher levels of IL-12 and IL-27, lower levels of IL-1B and IL-6, and no IL-23, making them poor promoters of Th17. The Langerin ${ }^{+}$dermal DC also inhibited the ability of Langerhans cells and classic DCs to promote Th17 responses. Interestingly, IL-12 and IL-27 as well as IFN- $\gamma$ from Th1 cells inhibit Th17 differentiation 
and proliferation. In this cutaneous Candida model, the absence of these cytokines was associated with elevated Th17 responses. Thus, presentation of the same antigen by Langerhans and Langerin ${ }^{+}$dermal DCs can promote opposing effects through the elaboration of polarizing cytokines that enable the development of Th1 and Th17 responses. Moreover, researchers have identified a subset of DCs that skews differentiation toward Th17 cells, which are instrumental in antifungal immunity $(32,46)$.

In the Peyer's patches, DCs are divided into DEC205+/DEC205- DCs; however, most of these DCs are $\mathrm{CD} 8 \mathrm{a}^{+}$and $\mathrm{CD} 11 \mathrm{~b}^{\mathrm{lo}}$ and are mainly present in the T cell-rich interfollicular regions (47), indicating a strong relationship between CD $8 a^{+} \mathrm{DCs}$ and $\mathrm{T}$ cell priming. The other important mucosal site is the respiratory tract, especially with regard to fungal infection. CD11c, CD11b, CD103, Langerin, and MHC class II are classic markers used to identify airway, alveolar, and interstitial (tissue) respiratory DCs (26). CD103 and CD11b are particularly useful as markers to divide respiratory DCs into two major types. Most DCs are single positive for either of these two markers $(48,49)$. $\mathrm{CD} 103^{+} \mathrm{DCs}$ play a vital role in antiviral responses at this site (44,50-52). Conversely, in experimental Aspergillus infection of the lung following spore inoculation, $\mathrm{CD}_{103}{ }^{+} \mathrm{DCs}$ were insignificant contributors to ingestion and delivery of spores into draining nodes. In addition, they did not influence the priming of T cells, whereas the $\mathrm{CD} 11 \mathrm{~b}^{+}$population of DCs played an almost exclusive role in these events (53). These observations underscore a remarkable difference in how select DC subsets operate in viral infection $\left(\mathrm{CD} 103^{+}\right)$as opposed to fungal infection $\left(\mathrm{CD} 11 \mathrm{~b}^{+}\right)$.

\section{CD8 $\alpha^{+}$Dendritic Cells}

As noted above, CD8 $a$ is present on various subsets of lymph node-resident DCs and some migratory DCs. The CD8 $a^{+}$DCs at various peripheral sites seem to have a prominent role in priming protective $\mathrm{T}$ cells. In most cases, CD8 $a$ expression on murine DCs exists as a homodimer (CD8 $a a)$, whereas $\mathrm{CD} 8^{+} \mathrm{T}$ cells express a heterodimer of $\mathrm{CD} 8 a \beta(54,55)$. $\mathrm{CD} 8^{+}$DCs represent the cDC phenotype through the induction of the Th1 response $(56,57)$. They also promote pathogen clearance as well as antigen cross-presentation and -processing of antigen from apoptotic cells $(19,54,58)$. CD8 ${ }^{+}$DCs also have a propensity for endocytosing apoptotic/dead cells (58) as well as live cells for cross-presentation (59). Antigen can be cross-presented on MHC class I when delivered within apoptotic vesicles (60). In experimental murine histoplasmosis, apoptotic macrophages containing $H$. capsulatum yeast antigen are taken up by DCs in vitro and serve as a potent mechanism for triggering CD8 $\mathrm{T}$ cell responses to the fungus. These $\mathrm{CD} 8^{+} \mathrm{T}$ cells are capable of producing type 1 cytokines including IFN- $\gamma$ as well as granzyme, and they contribute significantly to host resistance against histoplasmosis $(27,28)$. With their ability to prime both $\mathrm{CD} 4^{+}$and $\mathrm{CD}^{+} \mathrm{T}$ cells, cross-present antigen, and produce $\mathrm{IL}-12 \mathrm{p} 70, \mathrm{CD} 8^{+} \mathrm{DCs}$ are potent initiators of a proinflammatory Th1 response.

\section{Monocyte-Derived Dendritic Cells/Inflammatory Dendritic Cells}

Inflammatory moDCs make up a newly described DC population that can also be considered migratory. Two major types of monocytes are characterized as Ly6Chigh and Ly6Clow. Ly6 $\mathrm{C}^{\text {high }}$ and Ly6 $\mathrm{C}^{\text {low }}$ monocytes have differential expression of chemokine receptors CCR2 and CX3CR1, respectively. Despite some redundancy in chemokine receptors that mediate the migration of monocytes, it is generally accepted that CCR2 and CX3CR1 mediate migration of Ly6C $\mathrm{Chgh}^{\text {high }}$ and $6 \mathrm{C}^{\text {low }}$ monocytes, respectively $(61,62)$. Differential expression of chemokine receptors confers differences in function. During inflammation, Ly6C high $\mathrm{CCR} 2+\mathrm{CD} 11 \mathrm{~b}^{\text {high }}$ monocytes migrate to the site of infection and differentiate into DCs (63-66) (Figure 1). They have a critical role in the response to several medically important fungi. $\mathrm{CX} 3 \mathrm{CR} 1^{+}$monocytes appear to have a more regulatory/anti-inflammatory function (21). 
Migration of inflammatory monocytes is studied in two phases: egress out of the bone marrow and influx into inflammatory loci. CCR2 regulates the egress of Ly6Chigh cells out of the bone marrow during inflammation $(62,67)$. Thus, $\mathrm{CCR} 2^{-l-}$ animals are often used to investigate the role of Ly6Chigh inflammatory monocytes in vivo. However, CCR2 ${ }^{+}$ monocytes also serve as precursors for epidermal Langerhans cells and some dermal DCs, where migration to the draining lymph nodes is mainly modulated by CCR7 $(39,68)$. After emigration from the bone marrow, Ly6 $\mathrm{C}^{\text {high }} \mathrm{CD} 11 \mathrm{~b}^{\text {high }}$ monocyte influx into inflammatory loci is mediated by CD11b and other $\beta 2$ integrins $(61,69)$. Blocking CD11b/CD18 on monocytes prevents their interaction with endothelial cell ICAM-1 (intercellular adhesion molecule-1), preventing inflammatory monocytes from entering the inflammatory site (69).

Ly6 $\mathrm{C}^{\text {high }}$ inflammatory monocytes are critical for priming $\mathrm{T}$ cells and for resistance to fungal infections, including aspergillosis (70), cryptococcosis (66), and blastomycosis (32). Dermal moDCs display a phenotype similar to dermal DCs and Langerhans cells. They also utilize CCR7 to migrate into skin-draining lymph nodes $(65,68)$, whereas monocyte migration is predominantly CCR 2 dependent. In the lung, Ly6 $\mathrm{C}^{\text {high }}$ monocytes differentiate into $\mathrm{CD} 11 \mathrm{~b}^{+} \mathrm{DCs}$ and prime Th1 CD4 ${ }^{+} \mathrm{T}$ cells (66) (Figure 1).

More than any other DC subset, moDCs seem to have a critical role in antifungal immunity, particularly through the induction of Th1 cells. During Histoplasma infection for example, the yeasts reside chiefly within the inflammatory monocyte/macrophage population by day 7 post infection (71). Using CCR2 $2^{--}$mice, researchers have shown that this DC population plays a crucial part in driving a Th1 response and presenting antigen to $\mathrm{CD} 4^{+} \mathrm{T}$ cells $(61$, 72). If Th1 cytokines such as TNF- $a$ are neutralized in the lung, Histoplasma will redistribute to other antigen-presenting cell (APC) populations (71), reaffirming the connection between inflammatory monocytes and the induction of the Th1 phenotype. Utilizing CCR2 to control the inflammatory monocyte influx into the lung, infection with $A$. fumigatus and $C$. neoformans reveals a similar phenotype: Inflammatory monocytes are the source of $\mathrm{CD} 11 \mathrm{~b}^{+} \mathrm{DCs}$ that are critical for priming Th1 cells in the lung in response to these fungi $(66,70)$. CCR $2^{-1-}$ mice exhibit skewed $\mathrm{Th} 2$ responses and dramatically greater fungal burden in the lung compared with wild-type animals $(70,73)$. Interestingly, the defect in $\mathrm{CD} 4^{+} \mathrm{T}$ cell priming by inflammatory DCs during respiratory infection with $A$. fumigatus is restricted to the lung in CCR2 ${ }^{-/-}$animals and the defect does not occur in other lymphoid organs such as the spleen (70), underscoring a prominent compartment-specific role for this DC population within the lung versus other sites. Similarly, although Ly6Chigh CCR2 ${ }^{+}$ monocytes play a prominent role in delivering $B$. dermatitidis yeast into skin-draining lymph nodes after subcutaneous vaccine delivery, these functionally important CCR $2^{+}$cells play only a redundant role that can be compensated in CCR $2^{-/-}$mice by other skin migratory DC populations (32). Because the primary route of infection by fungal pathogens is through the lung, however, it is perhaps no surprise that the antifungal response in this organ demonstrates a heavy, often nonredundant, dependence on inflammatory moDCs.

\section{Dynamic Dendritic Cell Interactions for T Cell Priming}

Studies of the dynamic relationship between migratory and lymph node-resident DCs in the skin and skin-draining lymph node have revealed insight into how DC subsets work together to prime T cells. For example, lymph node-resident DCs trap antigen-specific CD4 T cells in the node where migratory DCs interact with these T cells, allowing clonal expansion (74). DCs also cooperate in vivo by transferring antigen from the migratory subset to the lymph node-resident subset. In terms of the herpes simplex virus 1, migratory DCs transfer antigen to lymph node-resident DCs, which prime $\mathrm{CD} 8^{+} \mathrm{T}$ cells (33). Antigen is displayed on MHC class I molecules of both DC subsets, but inhibiting the migratory subset blocks the ability of resident cells to prime $\mathrm{T}$ cells. There is also evidence that DCs transfer not only antigen, but also MHC molecules between subsets (75). 
Upon subcutaneous vaccination against $B$. dermatitidis, interstitial DCs, lymph noderesident DCs, and inflammatory moDCs collaborated in priming CD4 T cells and integrating an effective immune response. Ly6 $\mathrm{C}^{\text {high }}$ moDCs, and to a lesser extent $\mathrm{DEC} 205^{+}$dermal DCs, carry intact vaccine yeast into the draining lymph node where fungal antigen is transferred to the lymph node-resident DCs, which are requisite and nonredundant in priming antigen-specific $\mathrm{T}$ cells and vaccine-induced immunity to the fungus (32). This model highlights cooperation among DC subsets in vaccination against fungal disease. It also underscores the necessity of interplay between various DC subsets to generate an optimal vaccine immune response and engender protective immunity to lethal experimental challenge.

\section{PATTERN-RECOGNITION RECEPTORS, SIGNALING PATHWAYS, AND THEIR INFLUENCE ON T CELL DIFFERENTIATION AND ANTIFUNGAL IMMUNITY}

The innate immune system senses invading microbes through germline-encoded PRRs that bind conserved and invariant structures, termed pathogen-associated molecular patterns (PAMPs) (76). The fungal cell-wall components chitin (a polymer of $N$-acetylglucosamine), $a$ - and $\beta$-glucans (a polymer of glucose), and mannans (chains of $N$ - or $O$-linked mannose molecules) are the three major PAMPs that are unique to fungi and distinguish them from the mammalian host. Below, we discuss fungal PRRs and signaling pathways that impact the differentiation of antifungal $\mathrm{T}$ helper (Th) cells and the acquisition of protective immunity.

\section{Fungal Pattern-Recognition Receptors that Recognize Fungal Ligands}

The development of adaptive immunity is shaped by APCs expressing high levels of MHC, costimulatory molecules, and soluble mediators such as cytokines and chemokines that drive $\mathrm{T}$ cell differentiation. The innate recognition of fungi by PRRs induces intracellular signaling pathways giving rise to these responses. A wide gamut of membrane-bound and soluble, secreted PRRs recognize fungi (recently reviewed in Reference 77). Briefly, the PRRs that are best described for the recognition of fungi and induction of soluble mediators include the TLRs and the C-type lectin receptors.

The main TLRs involved in sensing fungal ligands such as zymosan, phospholipomannan, $O$-linked mannans, and fungal DNA are TLR2, TLR4, and TLR9 (reviewed in References 77, 78). Consequently, mice lacking the intracellular TLR signaling adaptor myeloid differentiation primary response protein 88 (MyD88) are highly susceptible to infections by B. dermatitidis, P. brasiliensis, A. fumigatus, C. neoformans, and C. albicans (79-82), emphasizing important roles for TLR signaling in antifungal immunity. However, conflicting reports on individual contributions of TLRs exist for almost every TLR and fungal pathogen $(80,83)$. The reason for these discrepancies is unclear, but the contribution of individual TLRs may vary depending on the experimental model and the fungal species.

Besides the TLRs, C-type lectin receptors expressed by myeloid cells are the key PRRs for fungal recognition and for the induction of protective immunity (reviewed in References 77, 78, 83-85). Dectin-1, Dectin-2, the macrophage-inducible C-type lectin (Mincle), the macrophage mannose receptor (MR) (CD206), and DC-SIGN (CD209) recognize fungal carbohydrates and modulate innate and adaptive immunity to fungi (86). Dectin-1 recognizes $\beta$-glucan on fungi and an unidentified ligand on mycobacteria (87-90). Dectin- $1^{-/-}$mice are vulnerable to primary pulmonary infection with $A$. fumigatus and Pneumocystis murina and systemic $C$. albicans (91-93). Langerin also recognizes $\beta$-glucan (in addition to mannose, fucose, and GlcNAc structures) on fungi including Candida and Saccharomyces species as well as Malassezia furfur (94). 
Dectin-2 and Mincle recognize mannose-like structures. Soluble Mincle protein binds to $C$. albicans and $S$. cerevisiae extracts and to Malassezia sp. by selectively binding $a$-mannose $(95,96)$. Mincle $^{-/-}$mice show increased susceptibility to systemic $C$. albicans infection (95). Similarly, soluble recombinant Dectin-2-Fc binds to the cell wall of multiple fungi including $C$. albicans, $P$. brasiliensis, $H$. capsulatum, nonencapsulated $C$. neoformans, Microsporum audouinii, and Trichophyton rubrum, and the binding is blocked by mannan $(97,98)$. Terminal mannose residues on the surface of $C$. neoformans, $C$. albicans, and $P$. carinii are notably sensed by the MR (CD206) (77). MR-deficient mice do not exhibit impaired resistance to primary infection with $C$. albicans and $P$. carinii but are more susceptible to $C$. neoformans infection (99-101). Human DC-SIGN (CD209) recognizes several Candida species, $A$. fumigatus, Chrysosporium tropicum, and $C$. neoformans (102-104).

Although not strictly thought of as PRRs, the fibronectin receptor VLA-5 on DCs and the human complement receptor type 3 (CR3, CD11b/CD18) on alveolar macrophages recognize and bind cyclophilin A (CypA) $(105,106)$ and heat shock protein $60(107,108)$, respectively, on the surface of $H$. capsulatum. Whereas $a$-(1,3)-glucan positive and negative strains of $H$. capsulatum prevent initial recognition, binding, and phagocytosis by Dectin-1, either by masking $\beta$-glucan exposure through $a(1,3)$-glucan or some other unknown mechanism (109), cooperative recognition by CR3 and Dectin-1 facilitates the production of TNF- $a$ and IL- 6 by macrophages (110).

\section{Cross Talk, Multimerization, Clustering, and Synergy of Pattern-Recognition Receptors and Integration of Signal Transduction Pathways}

The recognition of fungal pathogens expressing multiple PAMPs requires coordinated PRR signaling for the induction of optimal innate and adaptive immune responses. One of the best illustrations of this concept is the interaction of Dectin-1 with other receptors. Although Dectin-1 can directly induce its own set of cytokines, Dectin-1 interaction with TLR2, TLR4, TLR5, TLR7, and TLR9 results in synergistic induction of IL-10, TNF- $a$, IL-2, IL-6, and IL-23 and downregulation of IL-12 $(111,112)$. The reciprocal regulation of IL-23 and IL-12 is likely to have consequences on the ensuing adaptive immune response (see below). The Dectin-1/TLR2 pathway can further synergize with the MR to augment IL-17 production by human peripheral blood mononuclear cells (PBMCs) $(113,114)$. In addition, Dectin-1 also functionally interacts with tetraspanins such as the leukocyte-specific CD37 and the ubiquitous CD63 $(115,116)$. CD37 interaction reduced Dectin-1-induced IL-6 production. As a result of this interaction, Dectin-1 may be organized in a microdomain platform that facilitates receptor clustering with TLRs, cross talk between PRRs, and integration of signal transduction pathways (117).

Unlike other innate PRRs such as the TLRs, Dectin-1 discriminates between soluble and particulate ligands (118). Particulate as well as live $S$. cerevisiae, $C$. albicans, and $A$. fumigatus, but not soluble $\beta$-glucan, activate Dectin-1 signaling by clustering the receptor in synapse-like structures from which regulatory tyrosine phosphatases CD45 and CD148 are excluded. CD45 and CD148 exclusion from the contact site of Dectin- 1 with the $\beta$-glucan particle may be necessary to remove these phosphatases from the synapse to permit productive receptor signaling. The phagocytic synapse provides a model mechanism by which innate immune receptors can distinguish direct microbial contact from detection of microbes at a distance.

C. neoformans mannoproteins synergize with TLR1/2, 3, 4, 7/8, and 9 ligands to stimulate enhanced production of proinflammatory cytokines such as TNF and IL-12 and chemokines from murine DC (119). Synergistic stimulation required the interaction of mannose residues on mannoproteins with the MR. The synergy between MRs and TLRs enhanced 
mannoprotein-specific $\mathrm{CD}^{+} \mathrm{T}$ cell responses. Thus, phagocytes produce augmented proinflammatory cytokines when stimulated with a combination of fungal mannan and TLR ligands in vitro.

PRR costimulation is necessary for clearance of Fonsecaea pedrosoi, the causative agent of chromoblastomycosis infection. The chronic nature of chromoblastomycosis and lack of inflammatory response by leukocytes is due to a lack of PRR costimulation (120). F. pedrosoi is recognized primarily by Mincle and signaling via the Syk/Card9 pathway, but the lack of sufficient costimulation of TLRs results in defective inflammatory responses. Exogenous administration of TLR agonists restores costimulatory cytokine production and resolves the infection in vivo. These results highlight the importance of coordinated PRR signaling and may provide a simple treatment strategy for these types of diseases, such as topical application of appropriate TLR ligands.

\section{The Role of Pattern-Recognition Receptors and Signaling Pathways for the Induction of Antifungal T Cell Differentiation and Adaptive Immunity}

It is well established that the adaptive immune response, in particular that of $\mathrm{T}$ cells, plays a pivotal role in antifungal host defense $(78,121)$. To induce antifungal T cells, innate PRRs on APCs sample fungal PAMPs and induce a cocktail of signature cytokines and costimulatory molecules that will determine the differentiation of naive $\mathrm{T}$ cells into $\mathrm{Th}$ subsets (122). Upon recognition of fungi, PRRs and signaling pathways engaged on APCs induce a myriad of cytokines, only some of which influence Th differentiation (reviewed in References 78, 123). Herein, we discuss only PRRs and signaling pathways inducing cytokines that lead to a distinct Th subset (Figure 2). The differentiation of Th1 and Th17 $\mathrm{CD} 4^{+} \mathrm{T}$ cells is of particular interest for the antifungal immunity because these cells produce proinflammatory cytokines such as IFN- $\gamma$ and IL-17 that are known to recruit and activate phagocytes to kill fungi.

\section{Dectin-1}

Dectin-1 was the first and is the best-studied non-TLR PRR shown to instruct differentiation of Th1 and Th17 cells. Dectin-1 triggers intracellular signaling via a hem-ITAM motif. Downstream signaling of Dectin-1 is complex and not fully understood (Figure 2). Dectin-1 signals through a Syk-dependent pathway leading to activation of the canonical NF- $\mathrm{\kappa B}$ subunits p65 and c-Rel as well as of the noncanonical NF- $\mathrm{kB}$ subunit RelB $(124,125)$. The extent of Card9 involvement in that pathway is currently a subject of controversy (126). Dectin-1 signaling also induces the activation of MAPKs and NFAT (127-129). Dectin-1 cross talk with TLRs (e.g., TLR2 and TLR4) occurs via a Syk-independent pathway through Raf-1, which integrates with the Syk pathway at the point of NF- $\mathrm{kB}$ activation (124). Thus, Dectin-1 induces two independent signaling pathways, one through Syk and one through Raf-1, to control adaptive immunity to fungi (125). Curdlan, a highly purified form of $\beta$ glucan, and $C$. albicans induce the production of IL- 6 and IL-23 and a little IL-12 to differentiate naive T cells into Th17 and Th1 cells (129). The balance toward a Th17 response is favored through the collaborative interaction of Dectin-1 with TLR2 that leads to the production of prostaglandin E2, which will upregulate the Th17-polarizing cytokines IL-6 and IL-23 (130). In addition, recognition of $\beta$-glucan, $A$. fumigatus, and $C$. albicans by Dectin-1 and TLR2 activates the NLRP3 inflammasome and leads to the production of bioactive IL-1 $\beta$ (131-135), which also promotes Th17 cell development and antifungal immunity. In a pulmonary model of $A$. fumigatus infection, Dectin- 1 decreased the production of IL-12 and IFN- $\gamma$ in innate cells, which decreased T-bet expression in $A$. fumigatus-specific CD4 T cells and enabled Th17 differentiation (136). Despite the importance of Dectin-1 and IL-1 $\beta$ to drive antifungal Th17 cells and resistance to $C$. 
albicans, A. fumigatus, and P. carinii (91-93), vaccine-induced Th17 cells and immunity to B. dermatitidis are independent of Dectin-1 and IL-1 $\beta$ (79).

\section{Dectin-2 and Mincle}

Whereas Dectin-1 recognizes $\beta$-glucan and recruits Syk directly (87-89), Dectin-2 and Mincle recognize mannose-like structures and require the adaptor $\mathrm{FcR} \gamma$ to activate Syk and Card9 (98, 137-139) (Figure 2). Upon Dectin-2 activation, ITAM association of the FcR $\gamma$ chain phosphorylates Syk to activate NF- $\mathrm{BB}$ in a Card9-dependent manner and MAPKs in a Card9-independent manner (140). Recognition of $\boldsymbol{a}$-mannans by Dectin-2 induces the differentiation of Th17 cells $(137,140,141)$. In a model of systemic $C$. albicans infection, blockade of Dectin-2 by monoclonal antibody or infection of Dectin- $2^{-/-}$mice abrogated the development of Candida-specific Th17 cells $(137,140)$. Mincle was initially implicated in host responses to $C$. albicans infection in a microarray screen of primary mouse macrophages exposed to live $C$. albicans (95). Later, a glycoconjugate microarray study found that Mincle preferentially recognizes Malassezia species via $a$-mannosyl residues but not via mannan (96). Although we know that Mincle induces the production of TNF- $a$, CXCL1, CXCL2, and IL-10 upon recognition of $C$. albicans, Malassezia, and F. pedrosoi, investigators have yet to determine whether Mincle engagement by fungal PAMPs determines antifungal Th subsets $(95,96,120)$. However, the detection of mycobacteria by Mincle via cell-wall glycolipid trehalose-6,6-dimycolate (TDM) or its synthetic analogue threhalose-6,6-dibehenate (TDB) induces Th1 and Th17 cells $(138,141)$. For that reason, TDB and TDM are currently being investigated as adjuvants for a subunit vaccine against Mycobacterium tuberculosis (87). Mincle-induced T cell differentiation requires the SykCard9-Bcl10-Malt1 signaling pathway $(141,142)$; consequently, the Card9 pathway is required for resistance to $M$. tuberculosis (143).

\section{The Mannose Receptor}

The MR has a short cytoplasmic tail that lacks classical signaling motifs, and its downstream signaling pathway is unknown (86). The MR can induce NF- $\kappa \mathrm{B}$ activation and the production of IL-12, GM-CSF, IL-8, IL-1 $\beta$, and IL-6 (144-147). The MR has been reported to induce Th17 cell differentiation of human T cells in response to $C$. albicans, but memory - and not naive-T cells were the major source of the IL-17-producing cells $(113,114)$. Because different sets of cytokines are required to prime naive $\mathrm{T}$ cells and propagate already primed memory $\mathrm{T}$ cells, the role of the MR in inducing Th17 cell differentiation remains inconclusive. Given that the TLR2/Dectin-1 pathway has a secondary amplification effect on MR-induced IL-17 production (113, 114), $C$. albicans-derived $\beta$-glucan may be more important for the differentiation of naive cells into Th17 cells, whereas the MR may play a more prominent role in triggering $\mathrm{IL}-17$ production by memory cells.

\section{Toll-Like Receptors}

After ligand binding, TLRs dimerize and undergo conformational changes to bind Toll/IL-1 receptor (TIR) domain-containing adaptor molecules (e.g., MyD88 and TRIF) to the TIR domain of the TLR (148). MyD88 and TRIF activate distinct signaling pathways, inducing the production of proinflammatory cytokines and type I IFNs, respectively (reviewed in Reference 148). TLR2, TLR4, and TLR9 require MyD88 for signaling and activation of NF$\mathrm{KB}$ and MAPKs, resulting in the production of proinflammatory cytokines (Figure 2). In addition to proinflammatory signals, stimulation of TLR4 and TLR9, but not TLR2, induces type I IFN production that is dependent on the TRIF signaling pathway.

Because MyD88 is instrumental in priming Th1 cells in response to fungi (149), it is generally thought that antifungal TLRs induce a Th1 response. The role of TLRs for the induction of antifungal Th17 cells is less clear. Memory, but not naive, human $\mathrm{CD} 4^{+} \mathrm{T}$ cells 
produced IL-17 in response to zymosan in vitro (150). By using naive fungus-specific TCR transgenic cells, a recent study demonstrated that TLRs, and not Dectin-1 and IL-1R signaling, are required for the development of vaccine-induced Th17 cells and resistance to B. dermatitidis infection (79). The identity of the TLR(s) driving this response is unknown.

TLR2-Although TLR-mediated signaling generally favors a Th1 response, activation of TLR 2 by $C$. albicans is less inflammatory and can promote Th 2 responses through IL-10 production $(82,151,152)$. Consequently, TLR2 ${ }^{-/}$mice showed increased resistance to disseminated candidiasis that was associated with increased IL-12 and IFN- $\gamma$ and decreased IL-10 production. The immunomodulatory effects by TLR 2 were mediated through Treg cells $(151,153)$. Further evidence for the anti-inflammatory role of TLR2 in the antifungal immune response was provided by two additional studies: First, recognition of zymosan by TLR2 and Dectin-1 induced regulatory-type DCs expressing IL-10 and TGF- $\beta$ in concert with diminished proinflammatory cytokines that induced tolerogenic $\mathrm{T}$ cell responses (154). Second, in a murine model of chronic pulmonary infection with $P$. brasiliensis, TLR2 deficiency led to minor differences in the levels of pulmonary type 1 and type 2 cytokines, but increased production of TGF- $\beta$, IL-6, IL-23, and IL-17 and reduced expansion of regulatory $\mathrm{CD} 4{ }^{+} \mathrm{CD} 25^{+} \mathrm{FoxP} 3^{+} \mathrm{T}$ cells $(155)$. Consequently, $\mathrm{T}$ cell immunity was skewed toward a Th17 phenotype with diminished Treg cell expansion, indicating that TLR2 decreases Th17 immunity and promotes induction of Treg cells in that model.

TLR4-Recognition of $C$. albicans-derived $O$-linked mannosyl residues by TLR4 promotes proinflammatory cytokines $(156,157)$. TLR4 is required for resistance to primary and secondary infection with Candida and $A$. fumigatus (82). In the absence of TLR4, the number of IFN- $\gamma$-producing $\mathrm{CD}^{+} \mathrm{T}$ cells is decreased in candidiasis or remains unchanged in aspergillosis, whereas the number of IL-4-producing $\mathrm{T}$ cells is increased in both fungal infections. Thus, it is believed that TLR4 is necessary for the development of antifungal Th1 immune responses $(82,158)$. By contrast, TLR4 binding of the $C$. neoformans cell-wall component glucuronoxylomannan does not induce cytokine production despite translocating NF- $\mathrm{kB}(159)$.

TLR9-Multiple studies have indicated that fungal DNA is recognized by TLR9. Cryptococcal DNA-triggered IL-12p40 and CD40 expression in murine DCs and activated NF-^B in TLR9-transfected HEK239 cells (160). Similarly, A. fumigatus DNA stimulated the production of proinflammatory cytokines in mouse and human DCs (161). Blockade of TLR9 in human monocytes and macrophages from TLR9 ${ }^{-/-}$mice produced less IL-10 than did controls when stimulated with $C$. albicans (162). Despite inducing significantly reduced numbers of IFN- $\gamma$-producing and increased numbers of IL-4-producing $\mathrm{CD} 4^{+} \mathrm{T}$ cells, TLR9 $^{-/}$mice were highly resistant to both pulmonary aspergillosis and primary mucosal candidiasis and reinfection $(82,162)$.

In summary, our knowledge of PRRs and signaling pathways that induce the differentiation of naive antifungal $\mathrm{T}$ cells is still limited. This is mostly due to the lack of known fungal antigens and clonally restricted T cells with complementary TCRs that would enable the study of fungus-specific T cell development. Currently, there are only two antifungal TCR transgenic adoptive transfer systems and no tetramers to endogenous fungal epitopes available to study differentiation of naive $\mathrm{T}$ cells into distinct Th subsets. Recent publications highlight the resolution power of these tools in visualizing the activation, proliferation, and trafficking of fungus-specific T cells to uncover the molecular, spatial, and temporal requirements of naive $\mathrm{T}$ cells during differentiation. During respiratory infection with $A$. fumigatus, fungus-specific Af3.16 TCR transgenic cells were primed incrementally, with TLR-mediated signals in the lymph node enhancing the potential for IFN $-\gamma$ production, whereas MyD88-independent signals promoted differentiation in the lung (149). MyD88- 
mediated signals are dispensable for recruitment of naive $\mathrm{T}$ cells to the draining lymph node, for proliferation and exit from the lymph node, and for entry into the lung airways. In contrast, MyD88 is necessary for full IFN- $\gamma$ production by antigen-specific T cells. The availability of $A$. fumigatus-specific TCR transgenic cells allowed fungal immunologists to compare $\mathrm{T}$ cell differentiation in response to fungi with that in other microbes. In contrast to A. fumigatus-specific $\mathrm{T}$ cells, influenza-specific $\mathrm{CD} 4^{+} \mathrm{T}$ cells produced large amounts of IFN- $\gamma$ in lymphoid tissues $(163,164)$. Recently, the Af3.19 T cell adoptive transfer system was instrumental in enabling researchers to uncover the role of Dectin-1 in limiting Th1 differentiation, thereby promoting Th17 cell development (136). Dectin-1-mediated signaling by CCR $2^{+} \mathrm{CD} 11 \mathrm{c}^{+}$moDCs controls the balance of Th1 versus Th17 differentiation by reducing IL-12 and IFN- $\gamma$ expression, which regulates T-bet expression in responding Af3.16 CD4 T cells. In the absence of IL-12 and IFN- $\gamma$ production by innate cells and T-bet expression by responding CD4 T cells, A. fumigatus-infected wild-type mice showed enhanced $\mathrm{T} 17$ differentiation.

The second antifungal TCR transgenic ( $B d 1807)$ mouse harbors T cells that recognize a shared, endogenous fungal epitope in $B$. dermatitidis, $H$. capsulatum, $C$. posadasii, and $P$. lutzii (165). Although the protective role of $A$. fumigatus-specific Af3.16 TCR transgenic cells has not been investigated, $B d 1807$ mice are known to harbor protective T cells because they have been generated from a protective $\mathrm{T}$ cell clone (166). Vaccine-induced Th17 and Th1 1807 cells protect vaccinated mice against experimental pulmonary blastomycosis, histoplasmosis, and coccidioidomycosis $(79,165)$. Because $\mathrm{T}$ cell responses are requisite for vaccine immunity against dimorphic fungi, investigators now have a tool to track and precisely enumerate antigen-specific T cells during differentiation and memory development.

\section{THE INTERFACE OF CYTOKINES AND CHEMOKINES IN MOLDING ADAPTIVE IMMUNITY TO FUNGI}

The robustness of the protective adaptive immune response to medically important fungi requires nurturing by cytokines and chemokines secreted in response to the infectious process. Chemokines serve a vital influence in mobilizing recruitment of cells to sites of fungal infections; beyond that function, they also support the formation of the adaptive immune response to fungi. In this way, there is an interrelationship between chemokines and cytokines that dictates, at least partially, the evolution of the adaptive immune response. In murine cryptococcosis and histoplasmosis, Th1 cells are vitally important to clearance (167-169). The absence of the chemokine receptor CCR2 produces a dominant Th2 response that exacerbates infection $(73,170,171)$. Despite differences in the genetic and biochemical composition of these two fungi, the mechanisms that promote $\mathrm{Th} 2$ responses manifest several common features. In both, there is a major defect in the recruitment of cDC to the lungs following pulmonary challenge, and that finding is coincident with the development of Th2 responses (Figure 3). Transfer of immature DC does not correct the defect and, in fact, may exacerbate it. In contrast, injection of mature DC loaded with antigen reduces the generation of IL-4 in an MHC class II-dependent manner $(72,172)$. These results suggest that the Th2 response is amplified by not only the paucity of DCs, but also the level of maturity of the DCs. One unexpected finding of these studies is that the decrement in IL-4 upon transfer of antigen-bearing mature DC did not modify the fungal burden. Only when $\mathrm{CD} 4^{+}$cells are eliminated prior to infection and concurrent with DC transfer is the fungal burden reduced to that seen in control animals (73). In both models, CCL2 and CCL7 are important in the response. In cryptococcal infection, the speculation is that these chemokines promote migration of DCs and, therefore, propel a protective Th1 response. In histoplasmosis, the presence of CCL7 and CCL2 diminishes the Th2 response without 
enhancing emigration of either DCs or any cell type into the lungs. The conclusion from this study is that CCL7 and CCL2 must constrain IL-4 generation directly.

In cryptococcosis, the absence of CCR2 is associated with a marked decrement in the production of IFN- $\gamma$ in the lungs, principally by Th1 cells (171). The lack of Th1 cells, as opposed to Th2 cells, in the lungs is caused by their failure to migrate from the draining lymph nodes. The migration of Th1 cells is dependent on the presence of CCL2. The reason that Th1 cells, but not Th2 cells, are trapped has not been identified. One potential explanation is that the former exclusively express CCR2, and these cells respond to a CCL2 gradient. By contrast, the $\mathrm{Th} 2$ response in histoplasmosis is restricted to the pulmonary system, and it develops in the presence of a robust Th1 response (73). In fact, the proportion of Th1 cells in the lungs of CCR $2^{-/}$mice infected with $H$. capsulatum is similar to that found in controls, and the IFN- $\gamma$ levels in the lungs are similar between knockout and wildtype mice. Moreover, there is no inherent Th2 bias in the lungs of uninfected CCR $2^{-/}$mice. The Th2 bias in the lungs of $H$. capsulatum-infected CCR $2^{-l-}$ mice is sculpted in the lung milieu by as yet undiscovered mediators.

The chemokine receptor CCR5, long known as a coreceptor for HIV, also shapes the adaptive immune response to fungal infections. The original finding reported that the absence of CCR5 enhances clearance of Leishmania by altering the trafficking of Treg cells to sites of infection (173). Subsequent studies in paracoccidioidomycosis and histoplasmosis have reported that $\mathrm{CCR}^{-/-}$mice manifest accelerated elimination of fungi $(174,175)$. In paracoccidioidomycosis, the absence of CCR5 is accompanied by fewer Treg cells in granulomas, which are smaller than in wild-type mice. The accelerated clearance is reversed by transfer of Treg cells. However, the simple lack of Treg cells is not the sole reason for enhanced clearance in $\mathrm{CCR}^{-/-}$mice infected with $H$. capsulatum. The explanation is that the decrement in Treg cells is accompanied by a marked increase in the number of Th17 cells. The ratio of Th17 to Treg cells is increased during the onset of the cellular immune response, and neutralization of IL-17A causes the fungal burden to increase to that found in wild type. However, anti-IL-17A does not cause a progressive infection, most likely as a result of a strong Th1 response. These findings in murine histoplasmosis should be contrasted with previous results in which IL-17 only minimally contributed to host defenses during primary infection in wild-type animals. Hence, only in the absence of CCR5 does the balance between Treg cells and Th17 cells affect the course of primary histoplasmosis. The possibility that Th17 cells are involved in host defenses in paracoccidioidomycosis is certainly tenable but unproven. In contrast to the advantage that the absence of CCR5 exerts on histoplasmosis or paracoccidioidomycosis, $\mathrm{CCR} 5^{-/}$mice infected with $C$. neoformans suffer a heightened severity of infection resulting in a pronounced increase in death attributable to central nervous system disease (176). The poor outcome in the central nervous system is likely the result of decreased mobilization of the inflammatory cells to this site.

Initially, studies in murine leishmaniasis indicated that $\mathrm{CCR}^{-/-}$Treg cells do not traffic to infected sites; however, the data in histoplasmosis reveal otherwise (175). Based on that finding, other considerations were entertained to explain the reduced number of Treg cells in the lungs of CCR5 ${ }^{-/}$mice. Naturally occurring Treg cells are of thymic origin, and they emigrate to the circulation. Examination of the thymus in the mutant mice reveals an entrapment of Treg cells as well as other single-positive T cells (177). The accumulation of Treg cells and other populations is ascribed to decrements in the transcription factor Krüppel-like factor 2 (KLF2) and the sphingosine phosphate receptor 1 (S1P1), which is regulated by this transcription factor. Both of these molecules are critical elements in the exit of thymocytes (178-180). In vitro, the CCR5 ligands CCL3, 4, and 5 enhance expression of KLF2 and S1P1 on CCR5 ${ }^{+/+}$thymocytes, providing an explanation of why 
these molecules may be downregulated in $\mathrm{CCR} 5^{-/}$mice (177). Alterations in thymic exit are not the only explanation for fewer Treg cells in these mice: The lung environment also does not support Treg cell growth in infected wild-type mice. In addition, cytokines in the lungs of infected $\mathrm{CCR}^{-/}$mice may not promote the generation of induced Treg cells.

CCL17 and its cognate receptor CCR4 impair the development of Th1 response in mice challenged with $A$. fumigatus (181). Mice lacking this receptor or recipients of neutralizing antibody to CCL17 manifest accelerated clearance of infection. In these mice, several changes are noted, including increases in IL-12 levels and in the numbers of macrophages and DCs. Given that CCL17 is a chemoattractant for Treg cells, the effect observed in these studies may be explained by altered trafficking of Treg cells. This effect may also be produced when CCL17 attracts Th2. The absence of CCR6 is associated with increased susceptibility to infection with $A$. fumigatus (182). Although this study focuses on DC migration to infected lungs, the absence of CCR6 may also impair migration of protective Th17 cells because they express this receptor.

\section{EFFECTOR T CELL FUNCTION IN ADAPTIVE IMMUNITY}

Once committed, T cells express effector function largely, but not exclusively, through release of cytokines that allow the host to restrict growth of the fungus. Although several cytokines are pivotal in mediating protective immunity, IFN- $\gamma$, TNF- $a$, and IL-17/22 are the three principal ones that contribute to protective immunity to several pathogenic fungi (183-185) (Figure 4). The action of the former two in fungal infections does not differ from that classically ascribed to them in other infectious diseases. They prompt release of nitric oxide and stimulate reactive oxygen intermediates, both of which are crucial cellular effectors. H. capsulatum, however, survives the release of reactive oxygen intermediates (186). TNF- $a$ is also necessary for generation of optimal T cell-dependent immunity in murine cryptococcosis and histoplasmosis $(187,188)$. The absence of this cytokine is associated with depressed recruitment of $\mathrm{T}$ cells in cryptococcosis and defective $\mathrm{T}$ cell function in histoplasmosis. In both models, administration of TNF- $a$-neutralizing antibody after infection is established does not affect the course of disease. These findings can be interpreted to mean that TNF- $a$ is necessary for the genesis of T cell immunity, but once T cells are operative, they do not require continued signaling from this cytokine.

Whereas the activities of IFN- $\gamma$ and TNF- $a$ are fairly well understood in the context of fungal infections, the influence of IL-17 is much more disparate. In models of $C$. albicans infection, there are disparate reports concluding that Th 17 cells promote protective

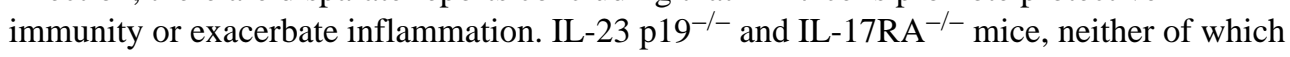
generate functional Th17 cells, manifest heightened fungal burdens in a model of mucosal disease (46). Fungal growth is restricted in the mucosa as a consequence of the upregulation of $\beta$-defensin 3 that exerts potent anticandidal activity. Likewise, the IL-17-IL-23 axis is necessary for optimal immunity in a model of Candida skin infection (189). Th17 cells may concomitantly synthesize IL-22: In particular experimental bacterial diseases, this cytokine is considered to be the principal influence on protective immunity, whereas IL-17 exerts a subordinate role (190). However, in mucosal candidiasis, protection was largely independent of IL-22. In contradistinction, others have demonstrated that IL-22 can substitute for IL-17 in IL-17RA ${ }^{-/-}$mice (191). It not only diminishes the fungal burden, but also maintains the integrity of the mucosal barrier in mice with candidiasis. Th17 cells are necessary for protective immunity in mice given a systemic challenge of $C$. albicans. In this scenario, Th17 cells are vital for optimal recruitment of neutrophils largely through the production of CXC chemokines (192). Although both models exemplify a need for IL-17 and Th17 cells, the basis for the antifungal effect differs strikingly between the two. Support for Th17 cells in protection against $C$. albicans has been noted in humans. Some patients with chronic 
mucocutaneous candidiasis exhibit genetic alterations of the IL-17 pathway (193). One individual had a deficiency in IL-17RA and others in IL-17F.

As in candidiasis, Th17 cells are a significant element in the adaptive immune response to $P$. brasiliensis. In mice genetically deficient in TLR2, Th17-mediated immunity appears in conjunction with the diminished expansion of Treg cells (155). Hence, TLR2 signaling maintains a balance of Th17 and Treg cells, and in its absence, there is a shift to a dominant Th17. However, there is a deleterious consequence to this imbalance as the host develops more severe immunopathology and tissue damage, largely as a result of an influx of neutrophils. These cells are recruited through IL-17-driven signaling despite the lower fungal burden. Although Th17 cells can promote disease pathology in models of primary, chronic pulmonary infection, vaccine-induced Th17 cells are necessary and sufficient to confer protection against secondary infection with $B$. dermatitidis, $H$. capsulatum, and $C$. posadasii. By contrast, Th1 cells are unexpectedly dispensable for vaccine immunity (79). Vaccine-induced Th17 cells mediate protection by recruiting and activating neutrophils and macrophages to the alveolar space. Vaccinated mice with polarized Th17 cells were healthy and showed no aberrant inflammation and tissue damage in the lung despite the presence of proinflammatory Th17 cells. The lack of tissue pathology and the beneficial role of vaccineinduced Th17 cells are likely due to the rapid clearance of infection before chronic inflammation.

Because microbes seek to survive in the host, they must develop the means to evade host defenses. Viable Candida releases a factor that inhibits IL-17 release by human peripheral blood mononuclear cells (194). This factor, as yet uncharacterized, inhibits indoleamine 2,3dioxygenase (IDO), but does not alter expression of PRRs that are important in the differentiation of Th17 cells. The result is an accumulation of 5-hydroxytryptophan metabolites that directly suppress IL-17 in vitro. Whether these metabolites alter expression of ROR $\gamma \mathrm{c}$ and whether this occurs at the level of the IL-17 promoter or gene remain unknown.

In contrast to the above findings, others have reported that Th17 cells dampen immunity to Candida and Aspergillus (195). An exaggerated Th17 response increases fungal burden by hindering expression of antifungal activity of neutrophils. In parallel, the exaggerated response provokes a hyperinflammatory response that induces tissue damage that does not undergo repair. The development of Th17-induced immune depression is dependent on signaling by IL-23. Heightened Th17 responses are observed in Toll IL-1 R $8^{-/-}$mice infected with either $C$. albicans or $A$. fumigatus (196). By contrast, mice lacking IL-1R displayed a highly depressed IL-17 response and, consequently, a decrement in immune pathology. Thus, IL-1 signaling boosts the Th17 response, and signaling through Toll IL-1R8 is a negative regulator of IL-17 synthesis.

A reconciliation of these vastly different conclusions has not been forthcoming. Given recent evidence that Th17 cells can be segregated into pathogenic and nonpathogenic cells depending on whether they produce GM-CSF (pathogenic) or IL-10 (nonpathogenic) raises the possibility that the disparate findings may be attributable to which phenotype of Th17 cell arises in each model $(197,198)$. Because the pathogenic cells are largely driven by induction of IL-23, differences in the production of this cytokine may well account for the appearance of two distinctive populations of Th17 cells. It also is interesting to note that the MR is crucial in the outgrowth of Th17 cells in vitro from human PBMCs in response to $C$. albicans, yet mice lacking this receptor are no more resistant or susceptible to this pathogen $(99,113)$. The Th17 response has not been studied in these mice, so there may well be an MR-independent pathway of Th17 cell development. 
In other experimental models of fungal diseases, especially those that chiefly affect the lung, Th17 cells contribute to control of infection, but they are not essential during primary infection. In murine histoplasmosis, neutralization of IL-17 induces a modest increase in fungal burden while causing a sharp decrement in the number of leukocytes recruited to the lungs and increases in IL-6 and IL-10 (199). However, IL-17 neutralization in IL-6 ${ }^{-/-}$and IL-1 $10^{-/-}$mice did not alter the fungal burden, indicating that immunity in these mice is IL-17 independent. A more pronounced effect of IL-17 is noted in mice that possess IL-23 but not IL-12. These mice survive longer than those lacking IL-12 and IL-23. The increase in survival of mice capable of synthesizing only IL-23 is attributable to Th17 cells. This cell population is also not critically important in murine cryptococcosis or pneumocystosis (200-203). The absence of Th17 cells causes increases in fungal burden, but the presence of Th17 cells is not requisite for survival. The emergence of robust Th1 and Th17 cells constrains $C$. neoformans growth in the lungs, but it fails to halt the progression to distant sites including the central nervous system and spleen. IL-23 treatment of mice with cryptococcosis prolongs survival through the induction of Th17/22 cells, but this effect does not match that of IL-12 treatment (203).

\section{COUNTER-REGULATION OF PROTECTIVE IMMUNITY IN FUNGAL INFECTIONS}

The host combats invasion by the fungal pathogen by mounting a vigorous Th1 and/or Th17 response to quench unfettered growth of the microbe. This scenario produces a paradoxical situation: The fungus must employ all means necessary to survive, while the host must eliminate the fungus but not necessarily at the cost of massive tissue damage. Hence, the differentiation of Treg cells becomes a common thread for both the pathogen seeking to escape host defenses and the host seeking to ensure that its response is not without restraints.

\section{Treg Cells}

Treg cells have been described in several models of fungal infections and in humans with progressive infections. In candidiasis, increased numbers of these cells arise in response to systemic challenge, and the numbers are dictated by signaling through TLR2 $(151,153)$. Infection of mice absent this PRR is much better constrained than in wild-type mice, and this heightened clearance is accompanied by a sharp decline in the number of Treg cells and generation of IL-10. TLR2 signaling enhances proliferation of Treg cells in a MyD88dependent manner. In murine paracoccidioidomycosis, TLR2 and TLR4 signaling are independently important in the expansion of Treg cells. The absence of TLR2 results in a decrement in the number of Treg cells, and this alteration is associated with marked hyperinflammation and an increase in Th17 cells (155). In TLR4-deficient animals, Treg cells are much more numerous, but this increase is accompanied by a substantial impairment in host defenses. Thus, the temporal pattern of TLR 2 or TLR4 recognition by P. brasiliensis becomes a major determinant of infection outcome.

Likewise, in murine gastric candidiasis, Treg cells dampen inflammation and permit the fungus to survive. Thus, the fungus exists in tissue that lacks substantial inflammation. However, persistence of the fungus is beneficial in that it induces durable antifungal immunity (204). This description is similar to that originally reported for cutaneous leishmaniasis in which Treg cells thwarted the elimination of the parasite, but the existence of small numbers was required for secondary immunity (205). Tolerance to the existence of the fungus is dependent on Treg cells. Their ability to migrate to the site of infection requires expression of the TLR4 adaptor, TRIF, in DCs. Once cells have taken up residence in gastric tissues, $M y D 88$ expression in DCs limits the suppressor activity of Treg cells. Subsequent to the migration of Treg cells, Th1 cells arise and activate the IDO pathway, and 
the products of this pathway, particularly kynurenines, feed back to enhance Foxp3 and dampen ROR $\gamma \mathrm{c}$ (206). The anti-inflammatory properties of Treg cells and their ability to induce tolerance to a fungal pathogen have also been reported for infection with $A$. fumigatus $(207,208)$.

A serious consequence of TNF antagonist therapy is the rise in the number of intracellular infections, including those caused by $H$. capsulatum (209). A potential explanation for the escalation in the number of serious cases of disseminated histoplasmosis comes from studies that the efficacy of TNF antagonism in autoimmune diabetes or in rheumatoid arthritis is linked to the expansion and enhanced activity of Treg cells $(210,211)$. Although several studies unequivocally demonstrate that TNF is required for host resistance to $H$. capsulatum, none has explored whether Treg cells contribute to the death of animals lacking TNF. The administration of anti-TNF monoclonal antibody induces increased numbers of Treg cells in lungs of mice given a pulmonary challenge (212). This elevation is specific for TNF because mice lacking IFN- $\gamma$ or GM-CSF, both cytokines needed for resolution of infection, do not manifest increased numbers of these cells. Elimination of Treg cells improves survival in TNF-neutralized mice; conversely, adoptive transfer of them exaggerates infection. The deleterious effects of Treg cells during the course of infection require IL-10, but not TGF- $\beta$, IL-9, or IDO. These results support the concept that Treg cells may be a double-edged sword. On the one hand, they are vital to controlling inflammation; on the other, their suppressive functions may damage host immunity, allowing particular pathogens to escape from their confinement.

Treg cells have been identified in patients with the severest forms of paracoccidioidomycosis $(213,214)$. These patients typically manifest marked alterations in cellular immunity characterized by loss of delayed-type hypersensitivity in vivo and pronounced impairment in in vitro T cell-dependent assays. In patients with active disease, Treg cells from the peripheral blood are suppressive in vitro through the release of IL-10 and TGF- $\beta$; neutralization of both in vitro improved in vitro correlates of cellular immunity. Additional studies have identified Treg cells in infected granulomatous lesions of patients with paracoccidioidomycosis (214). Treg cells isolated from the lesions exert suppressor activity in a TGF- $\beta$-dependent manner. Despite the difficulties of assuring that the in vitro studies mimic the in vivo condition, it seems likely that Treg cells are operative in active paracoccidioidomycosis and contribute to the severity of disease.

Although much of the literature regarding Treg cells in fungal infections indicates that they may be harmful at least in terms of halting growth, they may also be beneficial. Treg cells have been reported to enhance production of the IL-17 family of cytokines by T cells, thus enabling a polarization of these T cells (215). This action facilitated the emergence of protective Th17 cells in a model of oral candidiasis. These dramatic findings should prompt additional investigation into the salutary effects of Treg cells beyond their anti-inflammatory properties.

Downregulation of adaptive immunity largely has centered on studies of Treg cells. However, these cells are not the only ones capable of impairing immunity. In murine candidiasis, a population of $\mathrm{CD} 80^{+} \mathrm{Gr}-1^{+}$myeloid cells inhibits generation of Th1 cells and thus exacerbates infection (216). Although originally considered to be neutrophils, they likely represent one of the family myeloid-derived suppressor cells, which inhibit immunity in cancer and other infectious diseases. These cells probably belong to the so-called granulocytic myeloid-derived suppressor cell lineage. 


\section{Th2 Responses in Fungal Infections}

Progressive fungal infections, especially those that are acquired via inhalation, are associated with a shift in dominance from Th1 to Th2. This finding has been most clearly demonstrated for infections with $C$. neoformans, $H$. capsulatum, and $C$. immitis and posadasii, although Th2 cells have also been implicated in disease exacerbation in candidiasis and aspergillosis $(73,169,217-221)$. The underlying basis for the appearance of an amplified Th2 immune response has not been clarified for any of these fungal diseases. No literature exists as to whether IL-25, IL-33, thymic stromal lymphopoietin, and/or IL-4 are responsible for the heightened Th2 responses. Th2 responses may develop coincident with a vigorous Th1 response, yet the net effect is poor control of the fungal burden. Hence, when exaggerated $\mathrm{Th} 2$ responses arise, it is obvious that they exert the dominant effect and seem to impede the activity of Th1 immunity. Another outcome aside from uncontrolled fungal growth is alteration in pulmonary physiology in which airway resistance increases, thus compounding the severity of infection (218). The impact on airway resistance appears to be indirectly related to IL-4, but to be a direct consequence of IgE production.

The mounting evidence is that a strong Th2 response induces alternatively activated macrophages that are permissive for intracellular fungal growth and may be impervious to signaling by IFN $-\gamma$. Alternatively activated macrophages display a number of characteristics including several molecular signatures such as Ym1 and FIZZ1, increased expression of transferrin and the MR, and enhanced activity of arginase 1 that potentially diminishes the amount of nitric oxide available for antifungal activity (222). On the basis of these findings, the permissiveness of alternatively activated macrophages is principally centered on impaired nitric oxide generation and enhanced uptake of iron through the transferrin receptor. However, in alternatively activated macrophages infected with $C$. neoformans, the enhancement of intracellular growth transpires concomitant with a decrement in expulsion of the fungus (223). The latter process, referred to as efferocytosis, leads to ejection of cryptococcal yeasts into the extracellular milieu while maintaining the functional abilities of the macrophage. Another mechanism by which IL-4 alters intracellular survival is enhancing zinc, rather than iron, transport into macrophages (224). Thus, activated macrophages inhibit intracellular growth of $H$. capsulatum by limiting zinc, and IL-4 exposure enhances intracellular content of this trace metal.

For the vast majority of fungi, Th2 responses are deleterious. The contradiction is pneumocystis in which IL-4 generation ameliorates infection similar to that seen for nematodes (225). Th2 cells are as attracted, as are Th1 cells, to the lungs of mice infected with $P$. murina, suggesting they may be important in constraining the fungus. The likely explanation for the importance of Th2 immunity is the induction of certain classes of antibody that are vital for clearing $P$. murina. Evidence for an antibody-independent effect of Th2 immunity has been reported in which alternatively activated macrophages driven by IL-13 and amplified by IL-33 are more fungicidal than are control macrophages. This finding provides additional support that Th2 immunity is a significant contributor to the elimination of this fungus.

\section{IMMUNOGLOBULINS AND ADAPTIVE IMMUNITY TO FUNGI}

Evidence for the contribution of antibodies to host defenses in naturally acquired infection with fungi is largely nonexistent. Studies were hampered by analysis of sera in which, though many clonal isotypes of antibodies were present, perhaps only a small number of the isotypes actually conferred protection. The ability to create monoclonal antibodies to fungal antigens made it possible for researchers to inquire if particular clonally derived antibodies could confer protection. The overwhelming evidence is that for numerous medically important fungi, most notably $C$. neoformans and $C$. albicans, antibodies confer protection 
in adoptive transfer studies (226-230). Antibodies also provide protection to intracellular pathogens such as Listeria monocytogenes, M. tuberculosis, and the fungal pathogen $H$. capsulatum (231-233). A limitation for antibodies in vaccine design is the need to ensure that only protective antibodies arise when a given immunogen is delivered. By contrast, antibodies as immunotherapy have a broad application and the potential for high efficacy.

Most of the protective antibodies described to date recognize surface molecules that include, but are not limited to, the capsule of cryptococcus, mannotriose, and $\beta$ glucan from $C$. albicans; $\beta$ glucan of $A$. fumigatus; heat shock protein 60 and histones from $H$. capsulatum; and kexin and glycoprotein 120 from $P$. murina $(231,234-240)$. Thus, there appear to be no common targets, as of yet, that encompass the various species of fungi. One intriguing prospect is $\beta$ glucan, although some fungi such as $H$. capsulatum have evolved mechanisms to mask surface expression of this carbohydrate (241).

The mechanism of action is multifactoral and varies considerably with the antibody and the pathogen. Although opsonization and complement activation account for a portion of the action, other antibody actions include modulating $\mathrm{T}$ cell-dependent immunity. This is most strikingly exemplified in studies in which antibody transfer enhances survival of mice without impacting the pathogen burden. In such scenarios, granuloma formation and inflammation are much more highly organized in the presence of antibodies than in their absence (242). Cytokine and chemokine responses also are modified by antibody administration, and the metabolic profile of the fungus is altered by antibody. Protective antibodies to $C$. neoformans augment fatty acid metabolism and inhibit protein translation, whereas nonprotective antibody does not modify the transcriptome (243). Antibody-coated fungi may be shuttled into different intracellular compartments that lead to the killing of the organism, and antibodies may be fungicidal. In aspergillosis, researchers have derived antibodies that inhibit hyphal growth (237), a process that is requisite for propagation of the infection. Antibodies to the capsule of $C$. neoformans modify the conformation of the carbohydrate surface. Those that are protective induce a punctate capsular distribution of antibody versus nonprotective antibodies that induce an annular appearance (242). Studies also have shown that antifungal monoclonal antibodies unexpectedly bind to surface receptors other than Fc receptors. For example, IgM antibodies to $C$. neoformans or to $H$. capsulatum attach to CD11b and CD11c integrins, thereby prompting phagocytosis (244). This finding contradicted years of work indicating that $C$. neoformans required complement for phagocytosis to occur.

Another strategy for eliciting protective antibodies that seems to surmount the necessity for a monoclonal antibody has been developed in combating Pneumocystis infection. Antibodymediated immunity is paramount in controlling this fungal pathogen. Many monoclonal and polyclonal antibodies have been developed to modify the course of infection. As this infection is the most prevalent respiratory pathogen of patients with AIDS, the challenges for immunotherapy have been limited given the poor immune responses. A recent strategy has identified mechanisms for immunotherapy that bypass the need for $\mathrm{CD} 4^{+} \mathrm{T}$ cells. DNA vaccination with a Pneumocystis antigen, kexin linked to CD40 ligand, induces a strong antibody response in mice, and this humoral response is highly protective against subsequent infection (238). This approach is highly desirable for patients who have $\mathrm{CD} 4^{+}$deficiency or dysfunction because it obviates the need in this population to induce a humoral response.

The widespread employment of this strategy will depend on finding the antigens that elicit the appropriate antibody response. 


\section{SUMMARY AND CONCLUSIONS}

In this review, we have highlighted the major advances in knowledge concerning the development, maintenance, and function of the adaptive immune response to the medically important fungi, which have great morphologic and genetic diversity. Common themes are apparent, but adaptive responses to each of the fungi may display unique characteristics depending on the biochemical composition of the morphotype, the size of the fungal cell, and the genetic program activated by the fungus to resist the host immune response. The benefits of unearthing the pathways that lead to adaptive immunity and the function of this response include the following: (a) the creation of vaccines to prevent or treat fungal diseases, $(b)$ better predictions of who will be at risk for serious fungal infections, and (c) the development of biological agents that bolster immunity in the face of severe and lifethreatening infections.

\section{Acknowledgments}

Work by the authors has been supported by various grants from the National Institutes of Health (AI-093553 to M.W., AI35681 and AI40996 to B.S.K., and AI-073337 and AI-083313 to G.S.D.) as well as the Merit Review 1BX000717 from the Veterans Affairs (also to G.S.D.).

\section{LITERATURE CITED}

1. Fröhlich-Nowoisky J, Pickersgill DA, Després VR, Pöschl U. High diversity of fungi in air particulate matter. Proc. Natl. Acad. Sci. USA. 2009; 106:12814-19. [PubMed: 19617562]

2. Hohl TM, Rivera A, Pamer EG. Immunity to fungi. Curr. Opin. Immunol. 2006; 18:465-72. [PubMed: 16765580]

3. Romani L. Cell-mediated immunity to fungi: a reassessment. Med. Mycol. 2008; 46:515-29. [PubMed: 19180748]

4. Cutler JE, Deepe GS Jr, Klein BS. Advances in combating fungal diseases: vaccines on the threshold. Nat. Rev. Microbiol. 2007; 5:13-28. [PubMed: 17160002]

5. Roeder A, Kirschning CJ, Rupec RA, Schaller M, Weindl G, Korting HC. Toll-like receptors as key mediators in innate antifungal immunity. Med. Mycol. 2004; 42:485-98. [PubMed: 15682636]

6. Chu JH, Feudtner C, Heydon K, Walsh TJ, Zaoutis TE. Hospitalizations for endemic mycoses: a population-based national study. Clin. Infect. Dis. 2006; 42:822-25. [PubMed: 16477560]

7. Agarwal R, Gupta D. Severe asthma and fungi: current evidence. Med. Mycol. 2010; 49(Suppl. 1):S150-57. [PubMed: 20662637]

8. Denning DW, O'Driscoll BR, Hogaboam CM, Bowyer P, Niven RM. The link between fungi and severe asthma: a summary of the evidence. Eur. Respir. J. 2006; 27:615-26. [PubMed: 16507864]

9. Romani L, Zelante T, De Luca A, Bozza S, Bonifazi P, et al. Indoleamine 2,3-dioxygenase (IDO) in inflammation and allergy to Aspergillus. Med. Mycol. 2009; 47(Suppl. 1):S154-61. [PubMed: 18608907]

10. Cassone A. Fungal vaccines: real progress from real challenges. Lancet Infect. Dis. 2008; 8:11424. [PubMed: 18222162]

11. Mochon AB, Cutler JE. Is a vaccine needed against Candida albicans? Med. Mycol. 2005; 43:97115. [PubMed: 15832554]

12. Deleted in proof

13. Steinman RM, Hemmi H. Dendritic cells: translating innate to adaptive immunity. Curr. Top. Microbiol. Immunol. 2006; 311:17-58. [PubMed: 17048704]

14. Pasare C, Medzhitov R. Toll-like receptors: linking innate and adaptive immunity. Microbes Infect. 2004; 6:1382-87. [PubMed: 15596124]

15. Manicassamy S, Pulendran B. Modulation of adaptive immunity with Toll-like receptors. Semin. Immunol. 2009; 21:185-93. [PubMed: 19502082]

16. Heath WR, Carbone FR. Dendritic cell subsets in primary and secondary T cell responses at body surfaces. Nat. Immunol. 2009; 10:1237-44. [PubMed: 19915624] 
17. Ramirez-Ortiz ZG, Lee CK, Wang JP, Boon L, Specht CA, Levitz SM. A nonredundant role for plasmacytoid dendritic cells in host defense against the human fungal pathogen Aspergillus fumigatus. Cell Host Microbe. 2011; 9:415-24. [PubMed: 21575912]

18. Segura E, Villadangos JA. Antigen presentation by dendritic cells in vivo. Curr. Opin. Immunol. 2009; 21:105-10. [PubMed: 19342210]

19. Villadangos JA, Schnorrer P. Intrinsic and cooperative antigen-presenting functions of dendriticcell subsets in vivo. Nat. Rev. Immunol. 2007; 7:543-55. [PubMed: 17589544]

20. Villadangos JA, Heath WR. Life cycle, migration and antigen presenting functions of spleen and lymph node dendritic cells: limitations of the Langerhans cells paradigm. Semin. Immunol. 2005; 17:262-72. [PubMed: 15946854]

21. Domínguez PM, Ardavín C. Differentiation and function of mouse monocyte-derived dendritic cells in steady state and inflammation. Immunol. Rev. 2010; 234:90-104. [PubMed: 20193014]

22. López-Bravo M, Ardavín C. In vivo induction of immune responses to pathogens by conventional dendritic cells. Immunity. 2008; 29:343-51. [PubMed: 18799142]

23. Villadangos JA, Young L. Antigen-presentation properties of plasmacytoid dendritic cells. Immunity. 2008; 29:352-61. [PubMed: 18799143]

24. Reis e Sousa C, Hieny S, Scharton-Kersten T, Jankovic D, Charest H, et al. In vivo microbial stimulation induces rapid CD40 ligand-independent production of interleukin 12 by dendritic cells and their redistribution to T cell areas. J. Exp. Med. 1997; 186:1819-29. [PubMed: 9382881]

25. den Haan JM, Bevan MJ. Constitutive versus activation-dependent cross-presentation of immune complexes by $\mathrm{CD}^{+}$and $\mathrm{CD}^{-}$dendritic cells in vivo. J. Exp. Med. 2002; 196:817-27. [PubMed: 12235214]

26. del Rio ML, Bernhardt G, Rodriguez-Barbosa JI, Förster R. Development and functional specialization of $\mathrm{CD}_{103}{ }^{+}$dendritic cells. Immunol. Rev. 2010; 234:268-81. [PubMed: 20193025]

27. Lin JS, Yang CW, Wang DW, Wu-Hsieh BA. Dendritic cells cross-present exogenous fungal antigens to stimulate a protective CD8 T cell response in infection by Histoplasma capsulatum. J. Immunol. 2005; 174:6282-91. [PubMed: 15879127]

28. Deepe GS Jr. Role of $\mathrm{CD}^{+}{ }^{+} \mathrm{T}$ cells in host resistance to systemic infection with Histoplasma capsulatum in mice. J. Immunol. 1994; 152:3491-500. [PubMed: 8144930]

29. Itano AA, Jenkins MK. Antigen presentation to naive CD4 T cells in the lymph node. Nat. Immunol. 2003; 4:733-39. [PubMed: 12888794]

30. Ingulli E, Ulman DR, Lucido MM, Jenkins MK. In situ analysis reveals physical interactions between $\mathrm{CD} 11 \mathrm{~b}^{+}$dendritic cells and antigen-specific CD4 T cells after subcutaneous injection of antigen. J. Immunol. 2002; 169:2247-52. [PubMed: 12193689]

31. Randolph GJ, Angeli V, Swartz MA. Dendritic-cell trafficking to lymph nodes through lymphatic vessels. Nat. Rev. Immunol. 2005; 5:617-28. [PubMed: 16056255]

32. Ersland K, Wüthrich M, Klein BS. Dynamic interplay among monocyte-derived, dermal, and resident lymph node dendritic cells during the generation of vaccine immunity to fungi. Cell Host Microbe. 2010; 7:474-87. [PubMed: 20542251]

33. Allan RS, Waithman J, Bedoui S, Jones CM, Villadangos JA, et al. Migratory dendritic cells transfer antigen to a lymph node-resident dendritic cell population for efficient CTL priming. Immunity. 2006; 25:153-62. [PubMed: 16860764]

34. Gretz JE, Norbury CC, Anderson AO, Proudfoot AE, Shaw S. Lymph-borne chemokines and other low molecular weight molecules reach high endothelial venules via specialized conduits while a functional barrier limits access to the lymphocyte microenvironments in lymph node cortex. J. Exp. Med. 2000; 192:1425-40. [PubMed: 11085745]

35. Itano AA, McSorley SJ, Reinhardt RL, Ehst BD, Ingulli E, et al. Distinct dendritic cell populations sequentially present antigen to CD4 T cells and stimulate different aspects of cell-mediated immunity. Immunity. 2003; 19:47-57. [PubMed: 12871638]

36. Iezzi G, Fröhlich A, Ernst B, Ampenberger F, Saeland S, et al. Lymph node resident rather than skin-derived dendritic cells initiate specific T cell responses after Leishmania major infection. J. Immunol. 2006; 177:1250-56. [PubMed: 16818784] 
37. Eidsmo L, Allan R, Caminschi I, van Rooijen N, Heath WR, Carbone FR. Differential migration of epidermal and dermal dendritic cells during skin infection. J. Immunol. 2009; 182:3165-72. [PubMed: 19234214]

38. Stoitzner P, Holzmann S, McLellan AD, Ivarsson L, Stossel H, et al. Visualization and characterization of migratory Langerhans cells in murine skin and lymph nodes by antibodies against Langerin/CD207. J. Investig. Dermatol. 2003; 120:266-74. [PubMed: 12542532]

39. Ginhoux F, Collin MP, Bogunovic M, Abel M, Leboeuf M, et al. Blood-derived dermal langerin ${ }^{+}$ dendritic cells survey the skin in the steady state. J. Exp. Med. 2007; 204:3133-46. [PubMed: 18086862]

40. Idoyaga J, Suda N, Suda K, Park CG, Steinman RM. Antibody to Langerin/CD207 localizes large numbers of $\mathrm{CD} 8 \mathrm{a}^{+}$dendritic cells to the marginal zone of mouse spleen. Proc. Natl. Acad. Sci. USA. 2009; 106:1524-29. [PubMed: 19168629]

41. Chang SY, Cha HR, Igarashi O, Rennert PD, Kissenpfennig A, et al. Cutting edge: Langerin ${ }^{+}$ dendritic cells in the mesenteric lymph node set the stage for skin and gut immune system crosstalk. J. Immunol. 2008; 180:4361-65. [PubMed: 18354155]

42. Segura E, Villadangos JA. Antigen presentation by dendritic cells in vivo. Curr. Opin. Immunol. 2009; 21:105-10. [PubMed: 19342210]

43. Romani N, Clausen BE, Stoitzner P. Langerhans cells and more: Langerin-expressing dendritic cell subsets in the skin. Immunol. Rev. 2010; 234:120-41. [PubMed: 20193016]

44. King IL, Kroenke MA, Segal BM. GM-CSF-dependent, CD103 ${ }^{+}$dermal dendritic cells play a critical role in Th effector cell differentiation after subcutaneous immunization. J. Exp. Med. 2010; 207:953-61. [PubMed: 20421390]

45. Igyártó BZ, Haley K, Ortner D, Bobr A, Gerami-Nejad M, et al. Skin-resident murine dendritic cell subsets promote distinct and opposing antigen-specific T helper cell responses. Immunity. 2011; 35:260-72. [PubMed: 21782478]

46. Conti HR, Shen F, Nayyar N, Stocum E, Sun JN, et al. Th17 cells and IL-17 receptor signaling are essential for mucosal host defense against oral candidiasis. J. Exp. Med. 2009; 206:299-311. [PubMed: 19204111]

47. Milling S, Yrlid U, Cerovic V, MacPherson G. Subsets of migrating intestinal dendritic cells. Immunol. Rev. 2010; 234:259-67. [PubMed: 20193024]

48. Sung SS, Fu SM, Rose CE Jr, Gaskin F, Ju ST, Beaty SR. A major lung CD103 ( $a$ E)- $\beta 7$ integrinpositive epithelial dendritic cell population expressing Langerin and tight junction proteins. J. Immunol. 2006; 176:2161-72. [PubMed: 16455972]

49. Beaty SR, Rose CE Jr, Sung SS. Diverse and potent chemokine production by lung CD11b ${ }^{+}$ dendritic cells in homeostasis and in allergic lung inflammation. J. Immunol. 2007; 178:1882-95. [PubMed: 17237439]

50. Bedoui S, Whitney PG, Waithman J, Eidsmo L, Wakim L, et al. Cross-presentation of viral and self antigens by skin-derived CD103 ${ }^{+}$dendritic cells. Nat. Immunol. 2009; 10:488-95. [PubMed: 19349986]

51. Henri S, Poulin LF, Tamoutounour S, Ardouin L, Guilliams M, et al. CD207 ${ }^{+} \mathrm{CD} 03^{+}$dermal dendritic cells cross-present keratinocyte-derived antigens irrespective of the presence of Langerhans cells. J. Exp. Med. 2010; 207:189-206. [PubMed: 20038600]

52. Kim TS, Hufford MM, Sun J, Fu YX, Braciale TJ. Antigen persistence and the control of local T cell memory by migrant respiratory dendritic cells after acute virus infection. J. Exp. Med. 2010; 207:1161-72. [PubMed: 20513748]

53. Hohl TM, Rivera A, Lipuma L, Gallegos A, Shi C, et al. Inflammatory monocytes facilitate adaptive CD4 T cell responses during respiratory fungal infection. Cell Host Microbe. 2009; 6:470-81. [PubMed: 19917501]

54. Shortman K, Heath WR. The CD8 ${ }^{+}$dendritic cell subset. Immunol. Rev. 2010; 234:18-31. [PubMed: 20193009]

55. Contreras V, Urien C, Guiton R, Alexandre Y, Vu Manh TP, et al. Existence of CD8a-like dendritic cells with a conserved functional specialization and a common molecular signature in distant mammalian species. J. Immunol. 2010; 185:3313-25. [PubMed: 20702727] 
56. Maldonado-López R, Moser M. Dendritic cell subsets and the regulation of Th1/Th2 responses. Semin. Immunol. 2001; 13:275-82. [PubMed: 11502162]

57. Maldonado-López R, De Smedt T, Michel P, Godfroid J, Pajak B, et al. CD8 $a^{+}$and CD8 $a^{-}$ subclasses of dendritic cells direct the development of distinct T helper cells in vivo. J. Exp. Med. 1999; 189:587-92. [PubMed: 9927520]

58. Iyoda T, Shimoyama S, Liu K, Omatsu Y, Akiyama Y, et al. The CD8 ${ }^{+}$dendritic cell subset selectively endocytoses dying cells in culture and in vivo. J. Exp. Med. 2002; 195:1289-302. [PubMed: 12021309]

59. Matheoud D, Perié L, Hoeffel G, Vimeux L, Parent I, et al. Cross-presentation by dendritic cells from live cells induces protective immune responses in vivo. Blood. 2010; 115:4412-20. [PubMed: 20308597]

60. Winau F, Weber S, Sad S, de Diego J, Hoops SL, et al. Apoptotic vesicles cross-prime CD8 T cells and protect against tuberculosis. Immunity. 2006; 24:105-17. [PubMed: 16413927]

61. Serbina NV, Jia T, Hohl TM, Pamer EG. Monocyte-mediated defense against microbial pathogens. Annu. Rev. Immunol. 2008; 26:421-52. [PubMed: 18303997]

62. Serbina NV, Pamer EG. Monocyte emigration from bone marrow during bacterial infection requires signals mediated by chemokine receptor CCR2. Nat. Immunol. 2006; 7:311-17. [PubMed: 16462739]

63. Lin SL, Castaño AP, Nowlin BT, Lupher ML Jr, Duffield JS. Bone marrow Ly6C ${ }^{+}$monocytes are selectively recruited to injured kidney and differentiate into functionally distinct populations. J. Immunol. 2009; 183:6733-43. [PubMed: 19864592]

64. Osterholzer JJ, Chen GH, Olszewski MA, Curtis JL, Huffnagle GB, Toews GB. Accumulation of $\mathrm{CD} 11 \mathrm{~b}^{+}$lung dendritic cells in response to fungal infection results from the CCR2-mediated recruitment and differentiation of Ly- $6 \mathrm{C}^{+}$monocytes. J. Immunol. 2009; 183:8044-53. [PubMed: 19933856]

65. León B, López-Bravo M, Ardavín C. Monocyte-derived dendritic cells formed at the infection site control the induction of protective T helper 1 responses against Leishmania. Immunity. 2007; 26:519-31. [PubMed: 17412618]

66. Deleted in proof

67. Engel DR, Maurer J, Tittel AP, Weisheit C, Cavlar T, et al. CCR2 mediates homeostatic and inflammatory release of $\mathrm{Gr}^{+}$monocytes from the bone marrow, but is dispensable for bladder infiltration in bacterial urinary tract infection. J. Immunol. 2008; 181:5579-86. [PubMed: 18832716]

68. Ohl L, Mohaupt M, Czeloth N, Hintzen G, Kiafard Z, et al. CCR7 governs skin dendritic cell migration under inflammatory and steady-state conditions. Immunity. 2004; 21:279-88. [PubMed: 15308107]

69. Shi C, Velázquez P, Hohl TM, Leiner I, Dustin ML, Pamer EG. Monocyte trafficking to hepatic sites of bacterial infection is chemokine independent and directed by focal intercellular adhesion molecule-1 expression. J. Immunol. 2010; 184:6266-74. [PubMed: 20435926]

70. Hohl TM, Rivera A, Lipuma L, Gallegos A, Shi C, et al. Inflammatory monocytes facilitate adaptive CD4 T cell responses during respiratory fungal infection. Cell Host Microbe. 2009; 6:470-81. [PubMed: 19917501]

71. Deepe GS Jr, Gibbons RS, Smulian AG. Histoplasma capsulatum manifests preferential invasion of phagocytic subpopulations in murine lungs. J. Leukoc. Biol. 2008; 84:669-78. [PubMed: 18577715]

72. Szymczak WA, Deepe GS Jr. Antigen-presenting dendritic cells rescue CD4-depleted CCR2 $2^{-/-}$ mice from lethal Histoplasma capsulatum infection. Infect. Immun. 2010; 78:2125-37. [PubMed: 20194586]

73. Szymczak WA, Deepe GS Jr. The CCL7-CCL2-CCR2 axis regulates IL-4 production in lungs and fungal immunity. J. Immunol. 2009; 183:1964-74. [PubMed: 19587014]

74. Allenspach EJ, Lemos MP, Porrett PM, Turka LA, Laufer TM. Migratory and lymphoid-resident dendritic cells cooperate to efficiently prime naive CD4 T cells. Immunity. 2008; 29:795-806. [PubMed: 18951047] 
75. de Heusch M, Blocklet D, Egrise D, Hauquier B, Vermeersch M, et al. Bidirectional MHC molecule exchange between migratory and resident dendritic cells. J. Leukoc. Biol. 2007; 82:86168. [PubMed: 17634280]

76. Medzhitov R. Recognition of microorganisms and activation of the immune response. Nature. 2007; 449:819-26. [PubMed: 17943118]

77. Brown GD. Innate antifungal immunity: the key role of phagocytes. Annu. Rev. Immunol. 2011; 29:1-21. [PubMed: 20936972]

78. Romani L. Immunity to fungal infections. Nat. Rev. Immunol. 2011; 11:275-88. [PubMed: 21394104]

79. Wüthrich M, Gern B, Hung CY, Ersland K, Rocco N, et al. Vaccine-induced protection against 3 systemic mycoses endemic to North America requires Th17 cells in mice. J. Clin. Investig. 2011; 121:554-68. [PubMed: 21206087]

80. Calich VL, Pina A, Felonato M, Bernardino S, Costa TA, Loures FV. Toll-like receptors and fungal infections: the role of TLR2, TLR4 and MyD88 in paracoccidioidomycosis. FEMS Immunol. Med. Microbiol. 2008; 53:1-7. [PubMed: 18384366]

81. Poeck H, Ruland J. ITAM receptor signaling and the NLRP3 inflammasome in antifungal immunity. J. Clin. Immunol. 2010; 30:496-501. [PubMed: 20401526]

82. Bellocchio S, Montagnoli C, Bozza S, Gaziano R, Rossi G, et al. The contribution of the Toll-like/ IL-1 receptor superfamily to innate and adaptive immunity to fungal pathogens in vivo. J. Immunol. 2004; 172:3059-69. [PubMed: 14978111]

83. Netea MG, Brown GD, Kullberg BJ, Gow NA. An integrated model of the recognition of Candida albicans by the innate immune system. Nat. Rev. Microbiol. 2008; 6:67-78. [PubMed: 18079743]

84. Kerrigan AM, Brown GD. Syk-coupled C-type lectin receptors that mediate cellular activation via single tyrosine based activation motifs. Immunol. Rev. 2010; 234:335-52. [PubMed: 20193029]

85. Kerrigan AM, Brown GD. Syk-coupled C-type lectins in immunity. Trends Immunol. 2011; 32:151-56. [PubMed: 21334257]

86. Willment JA, Brown GD. C-type lectin receptors in antifungal immunity. Trends Microbiol. 2008; 16:27-32. [PubMed: 18160296]

87. Werninghaus K, Babiak A, Gross O, Hölscher C, Dietrich H, et al. Adjuvanticity of a synthetic cord factor analogue for subunit Mycobacterium tuberculosis vaccination requires FcR $\gamma$-SykCard9-dependent innate immune activation. J. Exp. Med. 2009; 206:89-97. [PubMed: 19139169]

88. Underhill DM, Rossnagle E, Lowell CA, Simmons RM. Dectin-1 activates Syk tyrosine kinase in a dynamic subset of macrophages for reactive oxygen production. Blood. 2005; 106:2543-50. [PubMed: 15956283]

89. Rogers NC, Slack EC, Edwards AD, Nolte MA, Schulz O, et al. Syk-dependent cytokine induction by Dectin-1 reveals a novel pattern recognition pathway for $C$ type lectins. Immunity. 2005; 22:507-17. [PubMed: 15845454]

90. Reid DM, Gow NA, Brown GD. Pattern recognition: recent insights from Dectin-1. Curr. Opin. Immunol. 2009; 21:30-37. [PubMed: 19223162]

91. Taylor PR, Tsoni SV, Willment JA, Dennehy KM, Rosas M, et al. Dectin-1 is required for $\beta$ glucan recognition and control of fungal infection. Nat. Immunol. 2007; 8:31-38. [PubMed: 17159984]

92. Saijo S, Fujikado N, Furuta T, Chung SH, Kotaki H, et al. Dectin-1 is required for host defense against Pneumocystis carinii but not against Candida albicans. Nat. Immunol. 2007; 8:39-46. [PubMed: 17159982]

93. Werner JL, Metz AE, Horn D, Schoeb TR, Hewitt MM, et al. Requisite role for the Dectin-1 $\beta$ glucan receptor in pulmonary defense against Aspergillus fumigatus. J. Immunol. 2009; 182:493846. [PubMed: 19342673]

94. de Jong MA, Vriend LE, Theelen B, Taylor ME, Fluitsma D, et al. C-type lectin Langerin is a $\beta$ glucan receptor on human Langerhans cells that recognizes opportunistic and pathogenic fungi. Mol. Immunol. 2010; 47:1216-25. [PubMed: 20097424]

95. Wells CA, Salvage-Jones JA, Li X, Hitchens K, Butcher S, et al. The macrophage-inducible C-type lectin, mincle, is an essential component of the innate immune response to Candida albicans. J. Immunol. 2008; 180:7404-13. [PubMed: 18490740] 
96. Yamasaki S, Matsumoto M, Takeuchi O, Matsuzawa T, Ishikawa E, et al. C-type lectin Mincle is an activating receptor for pathogenic fungus, Malassezia. Proc. Natl. Acad. Sci. USA. 2009; 106:1897-902. [PubMed: 19171887]

97. McGreal EP, Rosas M, Brown GD, Zamze S, Wong SY, et al. The carbohydrate-recognition domain of Dectin-2 is a C-type lectin with specificity for high mannose. Glycobiology. 2006; 16:422-30. [PubMed: 16423983]

98. Sato K, Yang XL, Yudate T, Chung JS, Wu J, et al. Dectin-2 is a pattern recognition receptor for fungi that couples with the Fc receptor $\gamma$ chain to induce innate immune responses. J. Biol. Chem. 2006; 281:38854-66. [PubMed: 17050534]

99. Lee SJ, Zheng NY, Clavijo M, Nussenzweig MC. Normal host defense during systemic candidiasis in mannose receptor-deficient mice. Infect. Immun. 2003; 71:437-45. [PubMed: 12496194]

100. Swain SD, Lee SJ, Nussenzweig MC, Harmsen AG. Absence of the macrophage mannose receptor in mice does not increase susceptibility to Pneumocystis carinii infection in vivo. Infect. Immun. 2003; 71:6213-21. [PubMed: 14573639]

101. Dan JM, Kelly RM, Lee CK, Levitz SM. Role of the mannose receptor in a murine model of Cryptococcus neoformans infection. Infect. Immun. 2008; 76:2362-67. [PubMed: 18391001]

102. Mansour MK, Latz E, Levitz SM. Cryptococcus neoformans glycoantigens are captured by multiple lectin receptors and presented by dendritic cells. J. Immunol. 2006; 176:3053-61. [PubMed: 16493064]

103. Serrano-Gómez D, Domínguez-Soto A, Ancochea J, Jimenez-Heffernan JA, Leal JA, Corbi AL. Dendritic cell-specific intercellular adhesion molecule 3-grabbing nonintegrin mediates binding and internalization of Aspergillus fumigatus conidia by dendritic cells and macrophages. J. Immunol. 2004; 173:5635-43. [PubMed: 15494514]

104. Cambi A, Netea MG, Mora-Montes HM, Gow NA, Hato SV, et al. Dendritic cell interaction with Candida albicans critically depends on $N$-linked mannan. J. Biol. Chem. 2008; 283:20590-99. [PubMed: 18482990]

105. Gomez FJ, Pilcher-Roberts R, Alborzi A, Newman SL. Histoplasma capsulatum cyclophilin A mediates attachment to dendritic cell VLA-5. J. Immunol. 2008; 181:7106-14. [PubMed: 18981131]

106. Gildea LA, Morris RE, Newman SL. Histoplasma capsulatum yeasts are phagocytosed via very late antigen-5, killed, and processed for antigen presentation by human dendritic cells. J. Immunol. 2001; 166:1049-56. [PubMed: 11145684]

107. Long KH, Gomez FJ, Morris RE, Newman SL. Identification of heat shock protein 60 as the ligand on Histoplasma capsulatum that mediates binding to CD18 receptors on human macrophages. J. Immunol. 2003; 170:487-94. [PubMed: 12496435]

108. Newman SL, Bucher C, Rhodes J, Bullock WE. Phagocytosis of Histoplasma capsulatum yeasts and microconidia by human cultured macrophages and alveolar macrophages. Cellular cytoskeleton requirement for attachment and ingestion. J. Clin. Investig. 1990; 85:223-30. [PubMed: 2104879]

109. Edwards JA, Alore EA, Rappleye CA. The yeast-phase virulence requirement for $\boldsymbol{a}$-glucan synthase differs among Histoplasma capsulatum chemotypes. Eukaryot. Cell. 2011; 10:87-97. [PubMed: 21037179]

110. Lin JS, Huang JH, Hung LY, Wu SY, Wu-Hsieh BA. Distinct roles of complement receptor 3, Dectin-1, and sialic acids in murine macrophage interaction with Histoplasma yeast. J. Leukoc. Biol. 2010; 88:95-106. [PubMed: 20360401]

111. Dennehy KM, Ferwerda G, Faro-Trindade I, Pyz E, Willment JA, et al. Syk kinase is required for collaborative cytokine production induced through Dectin-1 and Toll-like receptors. Eur. J. Immunol. 2008; 38:500-6. [PubMed: 18200499]

112. Gerosa F, Baldani-Guerra B, Lyakh LA, Batoni G, Esin S, et al. Differential regulation of interleukin 12 and interleukin 23 production in human dendritic cells. J. Exp. Med. 2008; 205:1447-61. [PubMed: 18490488]

113. van de Veerdonk FL, Marijnissen RJ, Kullberg BJ, Koenen HJ, Cheng SC, et al. The macrophage mannose receptor induces IL-17 in response to Candida albicans. Cell Host Microbe. 2009; 5:329-40. [PubMed: 19380112] 
114. Levitz SM. Th17 cells bounce off the fungal wall. Cell Host Microbe. 2009; 5:311-13. [PubMed: 19380108]

115. Meyer-Wentrup F, Figdor CG, Ansems M, Brossart P, Wright MD, et al. Dectin-1 interaction with tetraspanin CD37 inhibits IL-6 production. J. Immunol. 2007; 178:154-62. [PubMed: 17182550]

116. Mantegazza AR, Barrio MM, Moutel S, Bover L, Weck M, et al. CD63 tetraspanin slows down cell migration and translocates to the endosomal-lysosomal-MIICs route after extracellular stimuli in human immature dendritic cells. Blood. 2004; 104:1183-90. [PubMed: 15130945]

117. Figdor CG, van Spriel AB. Fungal pattern-recognition receptors and tetraspanins: partners on antigen-presenting cells. Trends Immunol. 2010; 31:91-96. [PubMed: 20036798]

118. Goodridge HS, Reyes CN, Becker CA, Katsumoto TR, Ma J, et al. Activation of the innate immune receptor Dectin-1 upon formation of a "phagocytic synapse.". Nature. 2011; 472:47175. [PubMed: 21525931]

119. Dan JM, Wang JP, Lee CK, Levitz SM. Cooperative stimulation of dendritic cells by Cryptococcus neoformans mannoproteins and CpG oligodeoxynucleotides. PLoS ONE. 2008; 3:e2046. [PubMed: 18446192]

120. da Gloria Sousa M, Reid DM, Schweighoffer E, Tybulewicz V, Ruland J, et al. Restoration of pattern recognition receptor costimulation to treat chromoblastomycosis, a chronic fungal infection of the skin. Cell Host Microbe. 2011; 9:436-43. [PubMed: 21575914]

121. Romani L. Immunity to fungal infections. Nat. Rev. Immunol. 2004; 4:1-23. [PubMed: 14661066]

122. Iwasaki A, Medzhitov R. Regulation of adaptive immunity by the innate immune system. Science. 2010; 327:291-95. [PubMed: 20075244]

123. Bourgeois C, Majer O, Frohner IE, Tierney L, Kuchler K. Fungal attacks on mammalian hosts: pathogen elimination requires sensing and tasting. Curr. Opin. Microbiol. 2010; 13:401-8. [PubMed: 20538507]

124. Gringhuis SI, den Dunnen J, Litjens M, van der Vlist M, Wevers B, et al. Dectin-1 directs T helper cell differentiation by controlling noncanonical NF- $\kappa$ B activation through Raf-1 and Syk. Nat. Immunol. 2009; 10:203-13. [PubMed: 19122653]

125. Geijtenbeek TB, Gringhuis SI. Signalling through C-type lectin receptors: shaping immune responses. Nat. Rev. Immunol. 2009; 9:465-79. [PubMed: 19521399]

126. Bi L, Gojestani S, Wu W, Hsu YM, Zhu J, et al. CARD9 mediates dectin-2-induced I $\kappa$ B $a$ kinase ubiquitination leading to activation of NF- $\kappa \mathrm{B}$ in response to stimulation by the hyphal form of Candida albicans. J. Biol. Chem. 2010; 285:25969-77. [PubMed: 20538615]

127. Goodridge HS, Simmons RM, Underhill DM. Dectin-1 stimulation by Candida albicans yeast or zymosan triggers NFAT activation in macrophages and dendritic cells. J. Immunol. 2007; 178:3107-15. [PubMed: 17312158]

128. Gross O, Gewies A, Finger K, Schafer M, Sparwasser T, et al. Card9 controls a non-TLR signalling pathway for innate anti-fungal immunity. Nature. 2006; 442:651-56. [PubMed: 16862125]

129. LeibundGut-Landmann S, Gross O, Robinson MJ, Osorio F, Slack EC, et al. Syk- and CARD9dependent coupling of innate immunity to the induction of $\mathrm{T}$ helper cells that produce interleukin 17. Nat. Immunol. 2007; 8:630-38. [PubMed: 17450144]

130. Smeekens SP, van de Veerdonk FL, van der Meer JW, Kullberg BJ, Joosten LA, Netea MG. The Candida Th17 response is dependent on mannan- and beta-glucan-induced prostaglandin E2. Int. Immunol. 2010; 22:889-95. [PubMed: 21059767]

131. Gross O, Poeck H, Bscheider M, Dostert C, Hannesschläger N, et al. Syk kinase signalling couples to the Nlrp3 inflammasome for anti-fungal host defence. Nature. 2009; 459:433-36. [PubMed: 19339971]

132. Hise AG, Tomalka J, Ganesan S, Patel K, Hall BA, et al. An essential role for the NLRP3 inflammasome in host defense against the human fungal pathogen Candida albicans. Cell Host Microbe. 2009; 5:487-97. [PubMed: 19454352] 
133. Said-Sadier N, Padilla E, Langsley G, Ojcius DM. Aspergillus fumigatus stimulates the NLRP3 inflammasome through a pathway requiring ROS production and the Syk tyrosine kinase. PLoS ONE. 2010; 5:e10008. [PubMed: 20368800]

134. Kankkunen P, Teirilä L, Rintahaka J, Alenius H, Wolff H, Matikainen S. (1,3)- $\beta$-glucans activate both dectin-1 and NLRP3 inflammasome in human macrophages. J. Immunol. 2010; 184:633542. [PubMed: 20421639]

135. Poeck H, Ruland J. SYK kinase signaling and the NLRP3 inflammasome in antifungal immunity. J. Mol. Med. 2010; 88:745-52. [PubMed: 20401456]

136. Rivera A, Hohl TM, Collins N, Leiner I, Gallegos A, et al. Dectin-1 diversifies Aspergillus fumigatus-specific $\mathrm{T}$ cell responses by inhibiting T helper type $1 \mathrm{CD} 4 \mathrm{~T}$ cell differentiation. J. Exp. Med. 2011; 208:369-81. [PubMed: 21242294]

137. Robinson MJ, Osorio F, Rosas M, Freitas RP, Schweighoffer E, et al. Dectin-2 is a Syk-coupled pattern recognition receptor crucial for Th17 responses to fungal infection. J. Exp. Med. 2009; 206:2037-51. [PubMed: 19703985]

138. Yamasaki S, Ishikawa E, Sakuma M, Hara H, Ogata K, Saito T. Mincle is an ITAM-coupled activating receptor that senses damaged cells. Nat. Immunol. 2008; 9:1179-88. [PubMed: 18776906]

139. Stahl PD, Ezekowitz RA. The mannose receptor is a pattern recognition receptor involved in host defense. Curr. Opin. Immunol. 1998; 10:50-55. [PubMed: 9523111]

140. Saijo S, Ikeda S, Yamabe K, Kakuta S, Ishigame H, et al. Dectin-2 recognition of $a$-mannans and induction of Th17 cell differentiation is essential for host defense against Candida albicans. Immunity. 2010; 32:681-91. [PubMed: 20493731]

141. Schoenen H, Bodendorfer B, Hitchens K, Manzanero S, Werninghaus K, et al. Cutting edge: Mincle is essential for recognition and adjuvanticity of the mycobacterial cord factor and its synthetic analog trehalose-dibehenate. J. Immunol. 2010; 184:2756-60. [PubMed: 20164423]

142. Ishikawa E, Ishikawa T, Morita YS, Toyonaga K, Yamada H, et al. Direct recognition of the mycobacterial glycolipid, trehalose dimycolate, by C-type lectin Mincle. J. Exp. Med. 2009; 206:2879-88. [PubMed: 20008526]

143. Dorhoi A, Desel C, Yeremeev V, Pradl L, Brinkmann V, et al. The adaptor molecule CARD9 is essential for tuberculosis control. J. Exp. Med. 2010; 207:777-92. [PubMed: 20351059]

144. Taylor PR, Gordon S, Martinez-Pomares L. The mannose receptor: linking homeostasis and immunity through sugar recognition. Trends Immunol. 2005; 26:104-10. [PubMed: 15668126]

145. Zhang J, Zhu J, Imrich A, Cushion M, Kinane TB, Koziel H. Pneumocystis activates human alveolar macrophage NF- $\kappa$ B signaling through mannose receptors. Infect. Immun. 2004; 72:3147-60. [PubMed: 15155616]

146. Tachado SD, Zhang J, Zhu J, Patel N, Cushion M, Koziel H. Pneumocystis-mediated IL-8 release by macrophages requires coexpression of mannose receptors and TLR2. J. Leukoc. Biol. 2007; 81:205-11. [PubMed: 17020928]

147. Pietrella D, Corbucci C, Perito S, Bistoni G, Vecchiarelli A. Mannoproteins from Cryptococcus neoformans promote dendritic cell maturation and activation. Infect. Immun. 2005; 73:820-27. [PubMed: 15664921]

148. Akira S, Uematsu S, Takeuchi O. Pathogen recognition and innate immunity. Cell. 2006; 124:783-801. [PubMed: 16497588]

149. Rivera A, Ro G, Van Epps HL, Simpson T, Leiner I, et al. Innate immune activation and CD4 ${ }^{+} \mathrm{T}$ cell priming during respiratory fungal infection. Immunity. 2006; 25:665-75. [PubMed: 17027299]

150. Evans HG, Suddason T, Jackson I, Taams LS, Lord GM. Optimal induction of T helper 17 cells in humans requires $\mathrm{T}$ cell receptor ligation in the context of Toll-like receptor-activated monocytes. Proc. Natl. Acad. Sci. USA. 2007; 104:17034-39. [PubMed: 17942669]

151. Netea MG, Sutmuller R, Hermann C, Van der Graaf CA, Van der Meer JW, et al. Toll-like receptor 2 suppresses immunity against Candida albicans through induction of IL-10 and regulatory T cells. J. Immunol. 2004; 172:3712-18. [PubMed: 15004175]

152. Netea MG, Van der Meer JW, Kullberg BJ. Toll-like receptors as an escape mechanism from the host defense. Trends Microbiol. 2004; 12:484-88. [PubMed: 15488388] 
153. Sutmuller RP, den Brok MH, Kramer M, Bennink EJ, Toonen LW, et al. Toll-like receptor 2 controls expansion and function of regulatory T cells. J. Clin. Investig. 2006; 116:485-94. [PubMed: 16424940]

154. Dillon S, Agrawal S, Banerjee K, Letterio J, Denning TL, et al. Yeast zymosan, a stimulus for TLR2 and dectin-1, induces regulatory antigen-presenting cells and immunological tolerance. J. Clin. Investig. 2006; 116:916-28. [PubMed: 16543948]

155. Loures FV, Pina A, Felonato M, Calich VL. TLR2 is a negative regulator of Th17 cells and tissue pathology in a pulmonary model of fungal infection. J. Immunol. 2009; 183:1279-90. [PubMed: 19553529]

156. Netea MG, Gow NA, Munro CA, Bates S, Collins C, et al. Immune sensing of Candida albicans requires cooperative recognition of mannans and glucans by lectin and Toll-like receptors. J. Clin. Investig. 2006; 116:1642-50. [PubMed: 16710478]

157. Tada H, Nemoto E, Shimauchi H, Watanabe T, Mikami T, et al. Saccharomyces cerevisiae- and Candida albicans-derived mannan induced production of tumor necrosis factor $a$ by human monocytes in a CD14- and Toll-like receptor 4-dependent manner. Microbiol. Immunol. 2002; 46:503-12. [PubMed: 12222939]

158. Netea MG, Van der Graaf C, Van der Meer JW, Kullberg BJ. Recognition of fungal pathogens by Toll-like receptors. Eur. J. Clin. Microbiol. Infect. Dis. 2004; 23:672-76. [PubMed: 15322932]

159. Shoham S, Huang C, Chen JM, Golenbock DT, Levitz SM. Toll-like receptor 4 mediates intracellular signaling without TNF- $a$ release in response to Cryptococcus neoformans polysaccharide capsule. J. Immunol. 2001; 166:4620-26. [PubMed: 11254720]

160. Nakamura K, Miyazato A, Xiao G, Hatta M, Inden K, et al. Deoxynucleic acids from Cryptococcus neoformans activate myeloid dendritic cells via a TLR9-dependent pathway. J. Immunol. 2008; 180:4067-74. [PubMed: 18322216]

161. Ramirez-Ortiz ZG, Specht CA, Wang JP, Lee CK, Bartholomeu DC, et al. Toll-like receptor 9dependent immune activation by unmethylated CpG motifs in Aspergillus fumigatus DNA. Infect. Immun. 2008; 76:2123-29. [PubMed: 18332208]

162. van de Veerdonk FL, Netea MG, Jansen TJ, Jacobs L, Verschueren I, et al. Redundant role of TLR9 for anti-Candida host defense. Immunobiology. 2008; 213:613-20. [PubMed: 18950591]

163. Jelley-Gibbs DM, Brown DM, Dibble JP, Haynes L, Eaton SM, Swain SL. Unexpected prolonged presentation of influenza antigens promotes CD4 T cell memory generation. J. Exp. Med. 2005; 202:697-706. [PubMed: 16147980]

164. Roman E, Miller E, Harmsen A, Wiley J, Von Andrian UH, et al. CD4 effector T cell subsets in the response to influenza: heterogeneity, migration, and function. J. Exp. Med. 2002; 196:95768. [PubMed: 12370257]

165. Wüthrich M, Hung CY, Gern BH, Pick-Jacobs PC, Galles KJ, et al. A T-cell receptor transgenic mouse reactive with multiple systemic dimorphic fungi. J. Immunol. 2011; 187:1421-31. [PubMed: 21705621]

166. Wüthrich M, Filutowicz HI, Allen HL, Deepe GS, Klein BS. V $\beta 1^{+} \mathrm{J} \beta 1.1^{+} / \mathrm{Va} 2^{+} \mathrm{J} a 49^{+} \mathrm{CD} 4^{+} \mathrm{T}$ cells mediate resistance against infection with Blastomyces dermatitidis. Infect. Immun. 2007; 75:193-200. [PubMed: 17030569]

167. Allendoerfer R, Deepe GS Jr. Intrapulmonary response to Histoplasma capsulatum in $\gamma$ interferon knockout mice. Infect. Immun. 1997; 65:2564-69. [PubMed: 9199420]

168. Huffnagle GB. Role of cytokines in T cell immunity to a pulmonary Cryptococcus neoformans infection. Biol. Signals. 1996; 5:215-22. [PubMed: 8891197]

169. Zhou P, Sieve MC, Bennett J, Kwon-Chung KJ, Tewari RP, et al. IL-12 prevents mortality in mice infected with Histoplasma capsulatum through induction of IFN- $\gamma$. J. Immunol. 1995; 155:785-95. [PubMed: 7608555]

170. Traynor TR, Herring AC, Dorf ME, Kuziel WA, Toews GB, Huffnagle GB. Differential roles of CC chemokine ligand 2/monocyte chemotactic protein-1 and CCR2 in the development of T1 immunity. J. Immunol. 2002; 168:4659-66. [PubMed: 11971015]

171. Traynor TR, Kuziel WA, Toews GB, Huffnagle GB. CCR2 expression determines T1 versus T2 polarization during pulmonary Cryptococcus neoformans infection. J. Immunol. 2000; 164:202127. [PubMed: 10657654] 
172. Osterholzer JJ, Curtis JL, Polak T, Ames T, Chen GH, et al. CCR2 mediates conventional dendritic cell recruitment and the formation of bronchovascular mononuclear cell infiltrates in the lungs of mice infected with Cryptococcus neoformans. J. Immunol. 2008; 181:610-20. [PubMed: 18566428]

173. Yurchenko E, Tritt M, Hay V, Shevach EM, Belkaid Y, Piccirillo CA. CCR5-dependent homing of naturally occurring $\mathrm{CD}^{+}{ }^{+}$regulatory $\mathrm{T}$ cells to sites of Leishmania major infection favors pathogen persistence. J. Exp. Med. 2006; 203:2451-60. [PubMed: 17015634]

174. Moreira AP, Cavassani KA, Massafera Tristão FS, Campanelli AP, Martinez R, et al. CCR5dependent regulatory $\mathrm{T}$ cell migration mediates fungal survival and severe immunosuppression. J. Immunol. 2008; 180:3049-56. [PubMed: 18292527]

175. Kroetz DN, Deepe GS Jr. CCR5 dictates the equilibrium of proinflammatory $\mathrm{IL}-17^{+}$and regulatory Foxp $3^{+}$T cells in fungal infection. J. Immunol. 2010; 184:5224-31. [PubMed: 20335531]

176. Huffnagle GB, McNeil LK, McDonald RA, Murphy JW, Toews GB, et al. Cutting edge: role of C-C chemokine receptor 5 in organ-specific and innate immunity to Cryptococcus neoformans. J. Immunol. 1999; 163:4642-46. [PubMed: 10528159]

177. Kroetz DN, Deepe GS Jr. An aberrant thymus in CCR $5^{-1-}$ mice is coupled with an enhanced adaptive immune response in fungal infection. J. Immunol. 2011; 186:5949-55. [PubMed: 21478401]

178. Matloubian M, Lo CG, Cinamon G, Lesneski MJ, Xu Y, et al. Lymphocyte egress from thymus and peripheral lymphoid organs is dependent on S1P receptor 1. Nature. 2004; 427:355-60. [PubMed: 14737169]

179. Carlson CM, Endrizzi BT, Wu J, Ding X, Weinreich MA, et al. Kruppel-like factor 2 regulates thymocyte and T-cell migration. Nature. 2006; 442:299-302. [PubMed: 16855590]

180. Sebzda E, Zou Z, Lee JS, Wang T, Kahn ML. Transcription factor KLF2 regulates the migration of naive T cells by restricting chemokine receptor expression patterns. Nat. Immunol. 2008; 9:292-300. [PubMed: 18246069]

181. Carpenter KJ, Hogaboam CM. Immunosuppressive effects of CCL17 on pulmonary antifungal responses during pulmonary invasive aspergillosis. Infect. Immun. 2005; 73:7198-207. [PubMed: 16239514]

182. Phadke AP, Akangire G, Park SJ, Lira SA, Mehrad B. The role of CC chemokine receptor 6 in host defense in a model of invasive pulmonary aspergillosis. Am. J. Respir. Crit. Care Med. 2007; 175:1165-72. [PubMed: 17379855]

183. Romani L. Cell mediated immunity to fungi: a reassessment. Med. Mycol. 2008; 46:515-29. [PubMed: 19180748]

184. Zelante T, Iannitti R, De Luca A, Romani L. IL-22 in antifungal immunity. Eur. J. Immunol. 2011; 41:270-75. [PubMed: 21267995]

185. Vautier S, Sousa Mda G, Brown GD. C-type lectins, fungi and Th17 responses. Cytokine Growth Factor Rev. 2010; 21:405-12. [PubMed: 21075040]

186. Bullock WE, Wright SD. Role of the adherence-promoting receptors, CR3, LFA-1, and p150,95, in binding of Histoplasma capsulatum by human macrophages. J. Exp. Med. 1987; 165:195-210. [PubMed: 3025331]

187. Allendoerfer R, Deepe GS Jr. Blockade of endogenous TNF-aexacerbates primary and secondary pulmonary histoplasmosis by differential mechanisms. J. Immunol. 1998; 160:6072-82. [PubMed: 9637524]

188. Huffnagle GB, Toews GB, Burdick MD, Boyd MB, McAllister KS, et al. Afferent phase production of TNF- $a$ is required for the development of protective T cell immunity to Cryptococcus neoformans. J. Immunol. 1996; 157:4529-36. [PubMed: 8906831]

189. Kagami S, Rizzo HL, Kurtz SE, Miller LS, Blauvelt A. IL-23 and IL-17A, but not IL-12 and IL-22, are required for optimal skin host defense against Candida albicans. J. Immunol. 2010; 185:5453-62. [PubMed: 20921529]

190. Aujla SJ, Chan YR, Zheng M, Fei M, Askew DJ, et al. IL-22 mediates mucosal host defense against Gram-negative bacterial pneumonia. Nat. Med. 2008; 14:275-81. [PubMed: 18264110] 
191. De Luca A, Zelante T, D’Angelo C, Zagarella S, Fallarino F, et al. IL-22 defines a novel immune pathway of antifungal resistance. Mucosal Immunol. 2010; 3:361-73. [PubMed: 20445503]

192. Huang W, Na L, Fidel PL, Schwarzenberger P. Requirement of interleukin-17A for systemic antiCandida albicans host defense in mice. J. Infect. Dis. 2004; 190:624-31. [PubMed: 15243941]

193. Puel A, Cypowyj S, Bustamante J, Wright JF, Liu L, et al. Chronic mucocutaneous candidiasis in humans with inborn errors of interleukin-17 immunity. Science. 2011; 332:65-68. [PubMed: 21350122]

194. Cheng SC, van de Veerdonk F, Smeekens S, Joosten LA, van der Meer JW, et al. Candida albicans dampens host defense by downregulating IL-17 production. J. Immunol. 2010; 185:2450-57. [PubMed: 20624941]

195. Zelante T, De Luca A, Bonifazi P, Montagnoli C, Bozza S, et al. IL-23 and the Th17 pathway promote inflammation and impair antifungal immune resistance. Eur. J. Immunol. 2007; 37:2695-706. [PubMed: 17899546]

196. Bozza S, Zelante T, Moretti S, Bonifazi P, DeLuca A, et al. Lack of Toll IL-1R8 exacerbates Th17 cell responses in fungal infection. J. Immunol. 2008; 180:4022-31. [PubMed: 18322211]

197. El-Behi M, Ciric B, Dai H, Yan Y, Cullimore M, et al. The encephalitogenicity of $\mathrm{T}_{\mathrm{H}} 17$ cells is dependent on IL-1- and IL-23-induced production of the cytokine GM-CSF. Nat. Immunol. 2011; 12:568-75. [PubMed: 21516111]

198. Codarri L, Gyulveszi G, Tosevski V, Hesske L, Fontana A, et al. ROR ユt drives production of the cytokine GM-CSF in helper T cells, which is essential for the effector phase of autoimmune neuroinflammation. Nat. Immunol. 2011; 12:560-67. [PubMed: 21516112]

199. Deepe GS Jr, Gibbons RS. Interleukins 17 and 23 influence the host response to Histoplasma capsulatum. J. Infect. Dis. 2009; 200:142-51. [PubMed: 19469707]

200. Wozniak KL, Hardison SE, Kolls JK, Wormley FL. Role of IL-17A on resolution of pulmonary C. neoformans infection. PLoS ONE. 2011; 6:e17204. [PubMed: 21359196]

201. Hardison SE, Wozniak KL, Kolls JK, Wormley FL Jr. Interleukin-17 is not required for classical macrophage activation in a pulmonary mouse model of Cryptococcus neoformans infection. Infect. Immun. 2010; 78:5341-51. [PubMed: 20921149]

202. Rudner XL, Happel KI, Young EA, Shellito JE. Interleukin-23 (IL-23)-IL-17 cytokine axis in murine Pneumocystis carinii infection. Infect. Immun. 2007; 75:3055-61. [PubMed: 17403873]

203. Kleinschek MA, Müller U, Schütze N, Sabat R, Straubinger RK, et al. Administration of IL-23 engages innate and adaptive immune mechanisms during fungal infection. Int. Immunol. 2010; 22:81-90. [PubMed: 19951959]

204. Montagnoli C, Bacci A, Bozza S, Gaziano R, Mosci P, et al. B7/CD28-dependent CD4 ${ }^{+}$CD $25^{+}$ regulatory $\mathrm{T}$ cells are essential components of the memory-protective immunity to Candida albicans. J. Immunol. 2002; 169:6298-308. [PubMed: 12444136]

205. Belkaid Y, Piccirillo CA, Mendez S, Shevach EM, Sacks DL. CD4 ${ }^{+}$CD $25^{+}$regulatory T cells control Leishmania major persistence and immunity. Nature. 2002; 420:502-7. [PubMed: 12466842]

206. De Luca A, Montagnoli C, Zelante T, Bonifazi P, Bozza S, et al. Functional yet balanced reactivity to Candida albicans requires TRIF, MyD88, and IDO-dependent inhibition of Rorc. J. Immunol. 2007; 179:5999-6008. [PubMed: 17947673]

207. Montagnoli C, Bozza S, Gaziano R, Zelante T, Bonifazi P, et al. Immunity and tolerance to Aspergillus fumigatus. Novartis Found. Symp. 2006; 279:66-77. discussion 77-79, 216-19. [PubMed: 17278386]

208. Montagnoli C, Fallarino F, Gaziano R, Bozza S, Bellocchio S, et al. Immunity and tolerance to Aspergillus involve functionally distinct regulatory $\mathrm{T}$ cells and tryptophan catabolism. J. Immunol. 2006; 176:1712-23. [PubMed: 16424201]

209. Wallis RS, Broder MS, Wong JY, Hanson ME, Beenhouwer DO. Granulomatous infectious diseases associated with tumor necrosis factor antagonists. Clin. Infect. Dis. 2004; 38:1261-65. [PubMed: 15127338]

210. Ehrenstein MR, Evans JG, Singh A, Moore S, Warnes G, et al. Compromised function of regulatory T cells in rheumatoid arthritis and reversal by anti-TNFa therapy. J. Exp. Med. 2004; 200:277-85. [PubMed: 15280421] 
211. Lee LF, Xu B, Michie SA, Beilhack GF, Warganich T, et al. The role of TNF-ain the pathogenesis of type 1 diabetes in the nonobese diabetic mouse: analysis of dendritic cell maturation. Proc. Natl. Acad. Sci. USA. 2005; 102:15995-6000. [PubMed: 16247001]

212. Deepe GS Jr, Gibbons RS. TNF- $a$ antagonism generates a population of antigen-specific $\mathrm{CD} 4{ }^{+} \mathrm{CD} 25^{+} \mathrm{T}$ cells that inhibit protective immunity in murine histoplasmosis. J. Immunol. 2008; 180:1088-97. [PubMed: 18178849]

213. Cavassani KA, Campanelli AP, Moreira AP, Vancim JO, Vitali LH, et al. Systemic and local characterization of regulatory T cells in a chronic fungal infection in humans. J. Immunol. 2006; 177:5811-18. [PubMed: 17056505]

214. Ferreira MC, de Oliveira RT, da Silva RM, Blotta MH, Mamoni RL. Involvement of regulatory T cells in the immunosuppression characteristic of patients with paracoccidioidomycosis. Infect. Immun. 2010; 78:4392-401. [PubMed: 20643858]

215. Pandiyan P, Conti HR, Zheng L, Peterson AC, Mathern DR, et al. CD $4^{+} \mathrm{CD} 25^{+} \mathrm{Foxp} 3^{+}$regulatory T cells promote Th17 cells in vitro and enhance host resistance in mouse Candida albicans Th17 cell infection model. Immunity. 2011; 34:422-34. [PubMed: 21435589]

216. Mencacci A, Montagnoli C, Bacci A, Cenci E, Pitzurra L, et al. CD $80^{+} \mathrm{Gr}-1^{+}$myeloid cells inhibit development of antifungal Th1 immunity in mice with candidiasis. J. Immunol. 2002; 169:3180-90. [PubMed: 12218136]

217. Magee DM, Cox RA. Interleukin-12 regulation of host defenses against Coccidioides immitis. Infect. Immun. 1996; 64:3609-13. [PubMed: 8751906]

218. Jain AV, Zhang Y, Fields WB, McNamara DA, Choe MY, et al. Th2 but not Th1 immune bias results in altered lung functions in a murine model of pulmonary Cryptococcus neoformans infection. Infect. Immun. 2009; 77:5389-99. [PubMed: 19752036]

219. Haraguchi N, Ishii Y, Morishima Y, Yoh K, Matsuno Y, et al. Impairment of host defense against disseminated candidiasis in mice overexpressing GATA-3. Infect. Immun. 2010; 78:2302-11. [PubMed: 20231412]

220. Cenci E, Romani L, Mencacci A, Spaccapelo R, Schiaffella E, et al. Interleukin-4 and interleukin-10 inhibit nitric oxide-dependent macrophage killing of Candida albicans. Eur. J. Immunol. 1993; 23:1034-38. [PubMed: 8477799]

221. Cenci E, Perito S, Enssle KH, Mosci P, Latge JP, et al. Th1 and Th2 cytokines in mice with invasive aspergillosis. Infect. Immun. 1997; 65:564-70. [PubMed: 9009314]

222. Gordon S, Taylor PR. Monocyte and macrophage heterogeneity. Nat. Rev. Immunol. 2005; 5:953-64. [PubMed: 16322748]

223. Voelz K, Lammas DA, May RC. Cytokine signaling regulates the outcome of intracellular macrophage parasitism by Cryptococcus neoformans. Infect. Immun. 2009; 77:3450-57. [PubMed: 19487474]

224. Winters MS, Chan Q, Caruso JA, Deepe GS Jr. Metallomic analysis of macrophages infected with Histoplasma capsulatum reveals a fundamental role for zinc in host defenses. J. Infect. Dis. 2010; 202:1136-45. [PubMed: 20731582]

225. Nelson MP, Christmann BS, Werner JL, Metz AE, Trevor JL, et al. IL-33 and M2a alveolar macrophages promote lung defense against the atypical fungal pathogen Pneumocystis murina. J. Immunol. 2011; 186:2372-81. [PubMed: 21220696]

226. Dromer F, Charreire J, Contrepois A, Carbon C, Yeni P. Protection of mice against experimental cryptococcosis by anti-Cryptococcus neoformans monoclonal antibody. Infect. Immun. 1987; 55:749-52. [PubMed: 3546140]

227. Mukherjee J, Nussbaum G, Scharff MD, Casadevall A. Protective and nonprotective monoclonal antibodies to Cryptococcus neoformans originating from one B cell. J. Exp. Med. 1995; 181:405-9. [PubMed: 7807020]

228. Mukherjee J, Pirofski LA, Scharff MD, Casadevall A. Antibody-mediated protection in mice with lethal intracerebral Cryptococcus neoformans infection. Proc. Natl. Acad. Sci. USA. 1993; 90:3636-40. [PubMed: 8475112]

229. Han Y, Cutler JE. Antibody response that protects against disseminated candidiasis. Infect. Immun. 1995; 63:2714-19. [PubMed: 7790089] 
230. Han Y, Riesselman MH, Cutler JE. Protection against candidiasis by an immunoglobulin G3 (IgG3) monoclonal antibody specific for the same mannotriose as an IgM protective antibody. Infect. Immun. 2000; 68:1649-54. [PubMed: 10678984]

231. Nosanchuk JD, Steenbergen JN, Shi L, Deepe GS Jr, Casadevall A. Antibodies to a cell surface histone-like protein protect against Histoplasma capsulatum. J. Clin. Investig. 2003; 112:116475. [PubMed: 14561701]

232. Edelson BT, Cossart P, Unanue ER. Cutting edge: paradigm revisited: antibody provides resistance to Listeria infection. J. Immunol. 1999; 163:4087-90. [PubMed: 10510340]

233. Teitelbaum R, Glatman-Freedman A, Chen B, Robbins JB, Unanue E, et al. A mAb recognizing a surface antigen of Mycobacterium tuberculosis enhances host survival. Proc. Natl. Acad. Sci. USA. 1998; 95:15688-93. [PubMed: 9861031]

234. Guimarães AJ, Frases S, Gomez FJ, Zancopé-Oliveira RM, Nosanchuk JD. Monoclonal antibodies to heat shock protein 60 alter the pathogenesis of Histoplasma capsulatum. Infect. Immun. 2009; 77:1357-67. [PubMed: 19179416]

235. Han Y, Ulrich MA, Cutler JE. Candida albicans mannan extract-protein conjugates induce a protective immune response against experimental candidiasis. J. Infect. Dis. 1999; 179:1477-84. [PubMed: 10228070]

236. De Bernardis F, Boccanera M, Adriani D, Spreghini E, Santoni G, Cassone A. Protective role of antimannan and anti-aspartyl proteinase antibodies in an experimental model of Candida albicans vaginitis in rats. Infect. Immun. 1997; 65:3399-405. [PubMed: 9234804]

237. Torosantucci A, Bromuro C, Chiani P, De Bernardis F, Berti F, et al. A novel glyco-conjugate vaccine against fungal pathogens. J. Exp. Med. 2005; 202:597-606. [PubMed: 16147975]

238. Zheng M, Shellito JE, Marrero L, Zhong Q, Julian S, et al. CD4 ${ }^{+}$T cell-independent vaccination against Pneumocystis carinii in mice. J. Clin. Investig. 2001; 108:1469-74. [PubMed: 11714738]

239. Casadevall A, Feldmesser M, Pirofski LA. Induced humoral immunity and vaccination against major human fungal pathogens. Curr. Opin. Microbiol. 2002; 5:386-91. [PubMed: 12160857]

240. Feldmesser M. Prospects of vaccines for invasive aspergillosis. Med. Mycol. 2005; 43:571-87. [PubMed: 16396243]

241. Rappleye CA, Eissenberg LG, Goldman WE. Histoplasma capsulatum a-(1,3)-glucan blocks innate immune recognition by the $\beta$-glucan receptor. Proc. Natl. Acad. Sci. USA. 2007; 104:1366-70. [PubMed: 17227865]

242. Casadevall A, Pirofski LA. A reappraisal of humoral immunity based on mechanisms of antibody-mediated protection against intracellular pathogens. Adv. Immunol. 2006; 91:1-44. [PubMed: 16938537]

243. McClelland EE, Nicola AM, Prados-Rosales R, Casadevall A. Ab binding alters gene expression in Cryptococcus neoformans and directly modulates fungal metabolism. J. Clin. Investig. 2010; 120:1355-61. [PubMed: 20335660]

244. Taborda CP, Casadevall A. CR3 (CD11b/CD18) and CR4 (CD11c/CD18) are involved in complement-independent antibody-mediated phagocytosis of Cryptococcus neoformans. Immunity. 2002; 16:791-802. [PubMed: 12121661] 


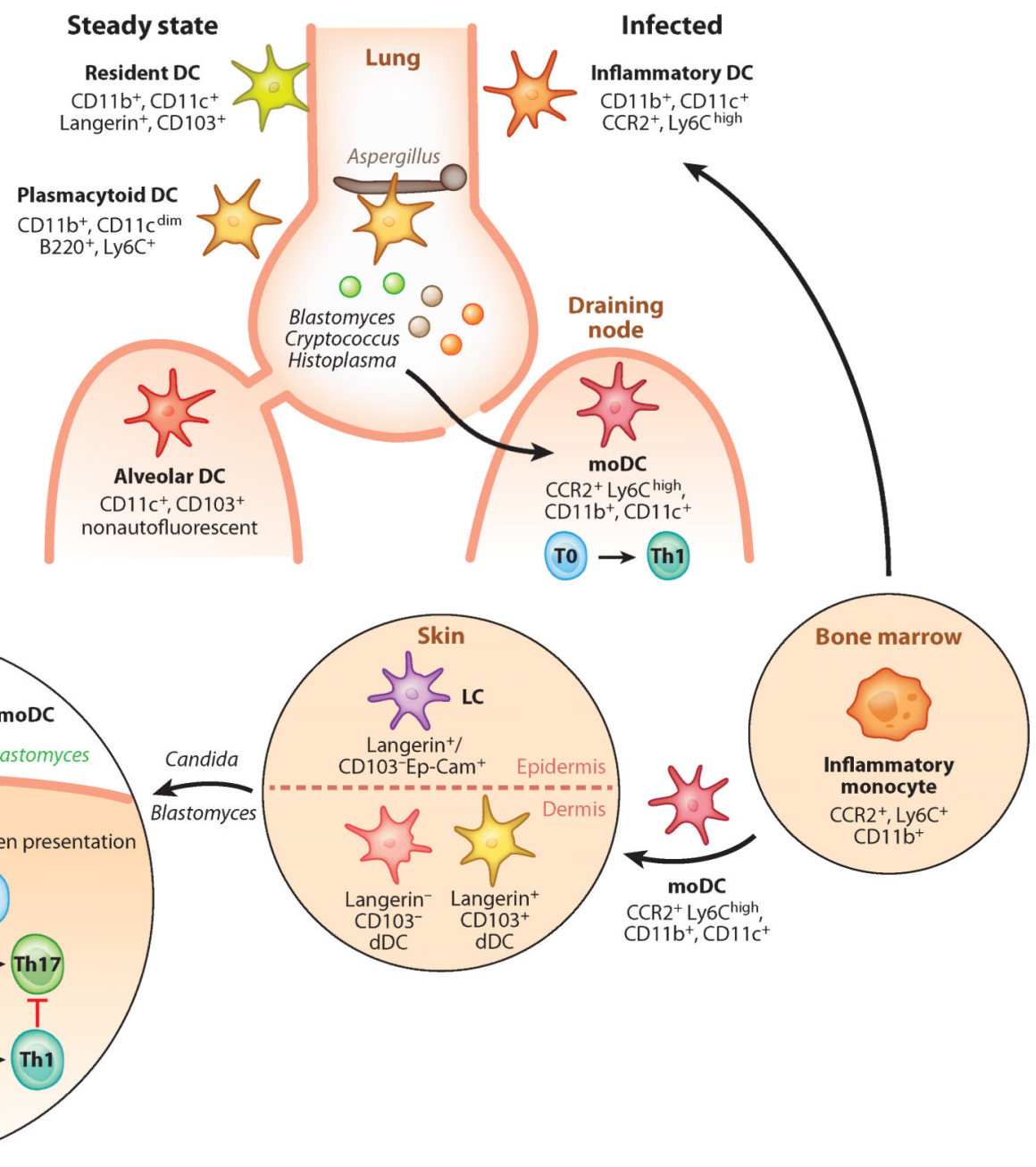

Figure 1.

Dendritic cells (DCs) and priming of adaptive immunity to fungi. At least five subsets of DCs participate in priming $\mathrm{T}$ cells during fungal infection. Lung DCs can be divided into either $\mathrm{CD}_{11} \mathrm{~b}^{+}$or $\mathrm{CD} 11 \mathrm{~b}^{-}$subsets. $\mathrm{CD} 103^{+}$resident conventional (c)DCs are important in response to viruses, inflammatory DCs participate in response to several fungal pathogens, and plasmacytoid (p)DCs are vital in immunity to Aspergillus (17). Inflammatory monocyte-derived DCs (moDCs) are CD11 ${ }^{+}$and Ly6Chigh. These cells express the chemokine receptor CCR2, which mediates egress from the marrow chiefly in response to the chemokines CCL2 and CCL7. In the absence of CCR2 (CCR2 ${ }^{-/-}$mice), animals evince a skewed Th response in the lung, dominated by Th2 cytokines (see Figure 3). Inflammatory moDCs also deliver subcutaneously injected vaccine yeast into draining lymph nodes (LNs), where they collaborate with migratory dermal and Langerhans DCs in priming CD4 T cells upon antigen transfer into LN-resident DCs. Dermal DCs (dDCs) elaborate IL-12 and IL-27 and efficiently prime Th1 cells, whereas Langerhans DCs elaborate IL-1 $\beta$, IL-6, and IL-23 and skew the response toward Th17. 


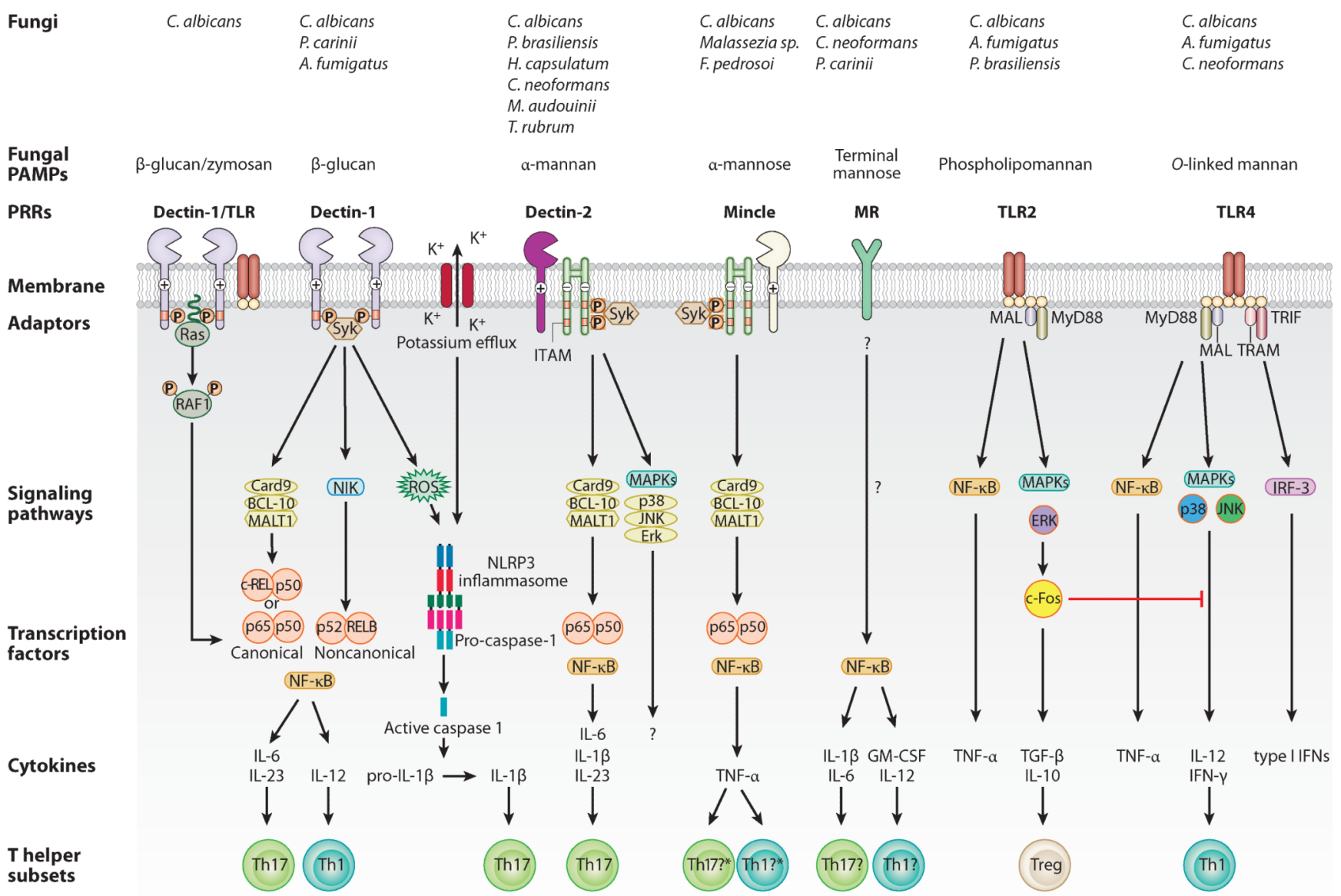

Figure 2.

Pattern-recognition receptors (PRRs) and signaling pathways that lead to differentiation of antifungal T helper (Th) cells. Recognition of fungal pathogen-associated molecular patterns (PAMPs) is mediated by Toll-like receptors (TLRs) and C-type lectin receptors (CLRs). The binding of fungi or $\beta$-glucan to Dectin-1 recruits SYK to the two phosphorylated receptors, which leads to the formation of a complex involving BCL10, Card9, and MALT1 (BCM). This results in the release of NF- $\kappa B$, consisting of either p65-p50 or REL-p50 dimers, into the nucleus (125). Syk activation also induces the noncanonical NF- $\mathrm{kB}$ pathway mediated by NF- $\kappa B$-inducing kinase (NIK) and the nuclear translocation of p52-RELB dimers. Dectin-1 enhances TLR2- and TLR4-induced cytokines in a Syk-independent manner through the serine/threonine protein kinase RAF1 by Ras proteins, which leads to the phosphorylation of p65 (124). These pathways lead to the production of, among other cytokines, IL-6 and IL-23, which induce Th17, and IL-12, which induces Th1. Dectin-1 recognition of Candidas albicans can also activate the NLRP3 inflammasome through a mechanism that involves Syk, ROS, and potassium efflux (135). Fungus-induced pro-IL-1 $\beta$ is cleaved by active caspase- 1 to bioactive IL- $1 \beta$ to favor Th17 development. Dectin-2 activation leads to FcR- $\gamma$-dependent recruitment and phosphorylation of Syk and activated NF- $\kappa$ B and MAPKs (p38, JNK, and Erk) (140). Card9 is required for the activation of NF$\kappa \mathrm{B}$ and production of cytokines that lead to Th17 cell differentiation. However, MAPK activation that occurs independent of Card9 does not lead to cytokine production (140). Recognition of $\boldsymbol{a}$-mannose in Malassezia species by Mincle activates the FcR $\boldsymbol{\gamma}$-Syk-Card9 pathway and translocates NF- $\mathrm{kB}$ into the nucleus to induce the activation of proinflammatory cytokines (96). Asterisk denotes that, although fungal PAMPs have not been shown to induce a distinct Th subset by this pathway, the mycobacterial cord factor 
and its synthetic analog are potent adjuvants for the differentiation of Mincle-induced Th1 and Th17 cells (141). The mannose receptor (MR) lacks a classical signaling motif in its short cytoplasmic tail, but it induces proinflammatory cytokines that have been implicated in Th17 and Th1 differentiation (86). Although MR-dependent triggering of human memory T cells produced IL-17, further studies with naive T cells will be necessary to demonstrate the role of the MR in Th17 cell differentiation (113). MyD88 is critical for the signaling of TLR2 and TLR4. Upon stimulation with phospholipomannan and $O$-linked mannan, TLR2 and TLR4, respectively, induce proinflammatory signals through the MAL-MyD88mediated NF- $\kappa$ B and MAPK pathways (148). TLR2 signaling is thought to generate weaker proinflammatory signals but to induce strong stimulation of TGF- $\beta$ and IL-10 that induces Treg cells $(151,153)$. In addition, TLR4 triggers the MyD88-independent, TRIF-dependent signaling pathway via TRAM and IRF3 to induce type I IFNs. 

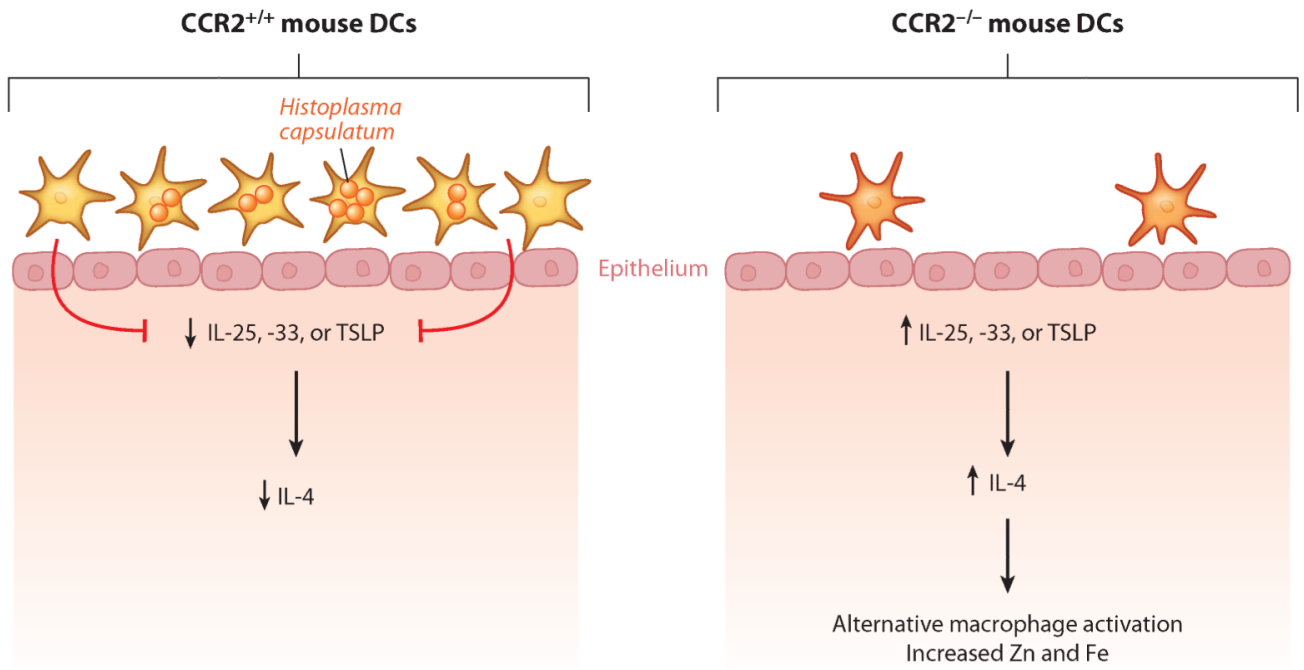

Figure 3.

Hypothetical depiction of control of IL-4 synthesis in CCR2 $2^{+/+}$and CCR2 $2^{-/-}$mice. Inflammatory antigen-laden dendritic cells (DCs) contact the epithelium and deliver signals that constrain the production of IL-25, IL-33, or thymic stromal lymphopoietin (TSLP), each of which can initiate the synthesis of IL-4. In CCR2 $2^{-/-}$mice, there is a paucity of these cells principally as a result of fewer inflammatory monocytes that can convert into DCs (73). The lack of DCs promotes the release of IL-25, IL-33, or TSLP, and one or more of these mediators amplifies IL-4 production. This scenario is mimicked in mice deficient in both CCL2 and CCL7. Thus, the regulation of IL-4 is dependent on the number of DCs that contact the epithelium. In mice deficient in either CCR2 or CCL2/7, amplification of IL-4 is a result of fewer DCs in the inflamed lungs. 


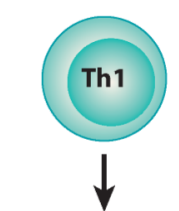

TNF, GM-CSF, IFN- $\gamma$

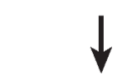

$\uparrow$ ROI, NO, MHC $\downarrow \mathrm{TR}, \mathrm{Fe}, \mathrm{Zn}$

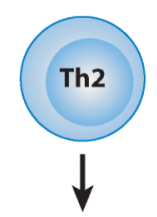

IL-4 and IL-13

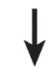

$\downarrow_{\text {NO }}$

$\uparrow$ Arginase, $\mathrm{Zn}$,
TR, and Fe

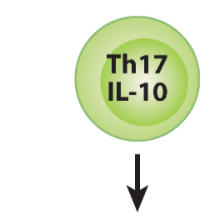

IL-17/22/10

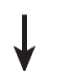

$\uparrow$ Defensins,

macrophage activation, and PMNs

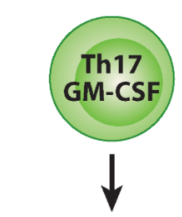

IL-17/22/GM-CSF

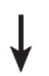

$\uparrow$ Inflammation

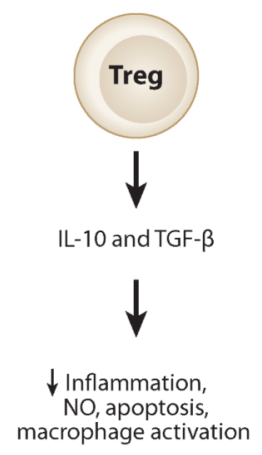

\section{Figure 4.}

Schematic illustration of the functional attributes of effector $\mathrm{T}$ cells in fungal infections. $\mathrm{T}$ helper (Th)1, Th2, Th17/22, and regulatory T (Treg) cells are depicted with their putative mechanisms of action. On the one hand, Th17 cells have been reported to facilitate clearance of fungal infection; on the other, they can exaggerate inflammation. Here, they have been subcategorized into Th17 IL- $10^{+}$and $\mathrm{Th} 17 \mathrm{GM}-\mathrm{CSF}^{+}$on the basis of the literature indicating that Th17GM-CSF${ }^{+}$are pathogenic T cells (196). 